\title{
A General Reliability and Safety Methodology and Its Application to Wind Energy Conversion Systems
}

Michael Edesess

Robert D. McConnell
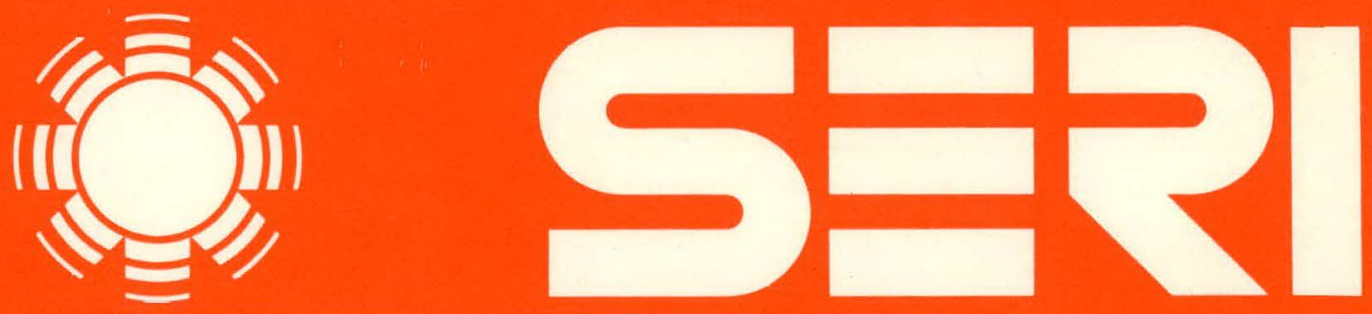

Solar Energy Research Institute A Division of Midwest Research Institute

1536 Cole Boulevard

Golden, Colorado 80401

Operaten for the

U.S. Department of Energy under Contract No. EG-77-C-01-4042 


\section{DISCLAIMER}

This report was prepared as an account of work sponsored by an agency of the United States Government. Neither the United States Government nor any agency Thereof, nor any of their employees, makes any warranty, express or implied, or assumes any legal liability or responsibility for the accuracy, completeness, or usefulness of any information, apparatus, product, or process disclosed, or represents that its use would not infringe privately owned rights. Reference herein to any specific commercial product, process, or service by trade name, trademark, manufacturer, or otherwise does not necessarily constitute or imply its endorsement, recommendation, or favoring by the United States Government or any agency thereof. The views and opinions of authors expressed herein do not necessarily state or reflect those of the United States Government or any agency thereof. 


\section{DISCLAIMER}

Portions of this document may be illegible in electronic image products. Images are produced from the best available original document. 
Printed in the Inited States of America

Available from:

National Technical Information Service

U.S. Department of Commerce

5285 Port Royal Road

Springfield, VA 22161

Price:

Microfiche $\$ 3.00$

Printed Copy $\$ 5.25$

\section{NOTICE}

This report was prepared as an account of work sponsored by the United States Govcrnment. Neither the United States nor the United States Department of Energy, nor any of their employees, nor any of their contractors, subcontractors, or their employees, makes any warranty, express or implied, or assumes any legal liability or responsibility for the accuracy, completeness or usefulness of any information, apparatus, product or process disclosed, or represents that its use would not infringe privately owned rights. 
SER I /TR-35-234

UC CATEGORY: UC-60

A GENERAL RELIABILITY AND SAFETY METHODOLOGY AND ITS APPLICATION

TO WIND ENERGY CONVERSION SYSTEMS

MICHAEL EDESESS

ROBERT D. MCCONNELL

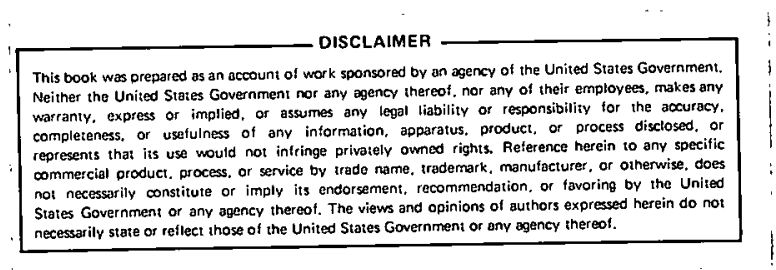

SEPTEMBER 1979

PREPARED UNDER TASK No. 3522.10

Solar Energy Research Institute

1536 Cole Boulevard

Golden, Colorado 80401

A Division of Midwest Research Institute

Prepared for the

U.S. Department of Energy

Contract No. EG.77.C. $01 \cdot 4042$ 
THIS PAGE

\section{WAS INTENTIONALLY LEFT BLANK}


SEP

$\operatorname{TR}-234$

FOREWORD

This report documents work done on SERI Task 3522.10 by members of the Systems Analysis Branch, Research Division.

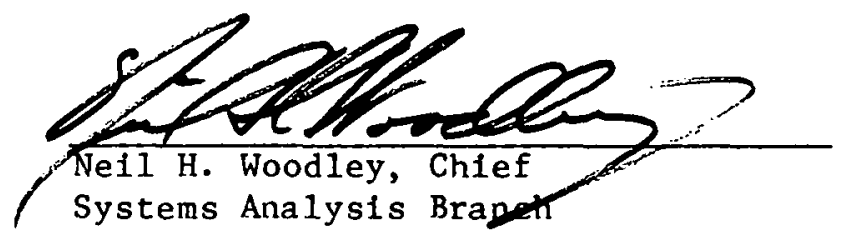

Approved for:

SOLAR ENERGY RESEARCH INSTITUTE

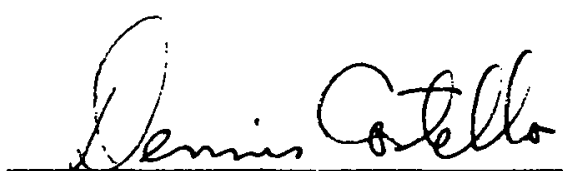

Dennis Costello, Acting Assistant Director Analysis Division

ii 
THIS PAGE

\section{WAS INTENTIONALLY LEFT BLANK}




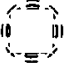

SUMMARY

In conventional system reliability calculations, each component may be in the Operable state or the Under Repair state. These calculations derive system unavailability, or the probability of the system's being down for repairs. By introducing a third component state between Operable and Under Repair--namely, Defective, But Defect Undetected--the methods developed in this report enable system safety projections to be made in addition to avallability projections. Also provided is a mechanism for computing the effect of inspection schedules on both safety and availability. A Reliability and Safety Program (RASP) is detailed which performs these computations and also calculates costs for system inspections and repairs. RASP is applied to a simplified wind energy conversion system example. 
THIS PAGE

\section{WAS INTENTIONALLY LEFT BLANK}


TABLE OF CONTENTS

Page

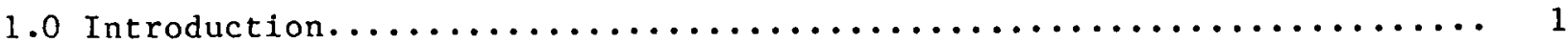

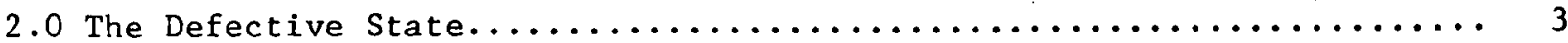

3.0 A Simple Example............................... 5

4.0 Generalized Component Calculations...................... 9

5.0 Generalized System Calculations............................. 13

6.0 A Simplified Wind Energy Conversion System Example............ 17

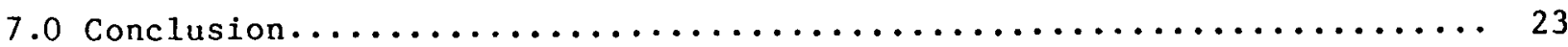

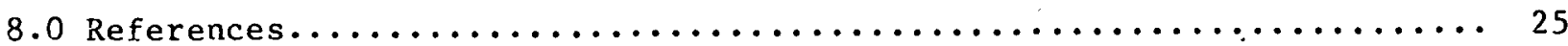

Appendix A: ' Output of Reliability and Safety Program for Simplified

Wind Energy Conversion System Example................. A-1

Appendix B: Listing of Reliability and Safety Program (RASP) ......... B-1 
THIS PAGE

\section{WAS INTENTIONALLY LEFT BLANK}




\section{LIST OF FIGURES}

Page

1-1 Performance Cycle for Each Component.................. 1

6-1 Simplified Wind Energy Conversion System............... 18

6-2 Simplified Wind Energy Conversion System with Crack Sensor...... 20

\section{LIST OF TABLES}

$\underline{\text { Page }}$

3-1 Braking System Data......................... 5

3-2 State Residence Probabilities..................... 6

3-3 State Residence Probabilities Expanded to Include Failed State... 7 


\section{SECTION 1 -0}

\section{INTRODUCTIOE}

In the electric power industry, a standard methodology has been developed for calculating system reliability [1-3]. Under this methodology it is assumed that each component of a system occupies either of two states: Operable or Under Repair. The duration of residence in the Operable state is the "time to failure," and the duration of residence in the Repair state is the "time to repair." This construction assumes that the Operable state lasts until failure and that the Repair state begins immediately thereafter.

In this simple form, the reliability methodology assumes perfect knowledge of the inoperability or "failure" of a component. For many components, however, there is an intermediate state between Operable and Under Repair which is of serious concern. This intermediate state we shall call "Defective, But Defect Undetected." Thus the cycle of performance for each component may be diagrammed as in Figure 1-1.

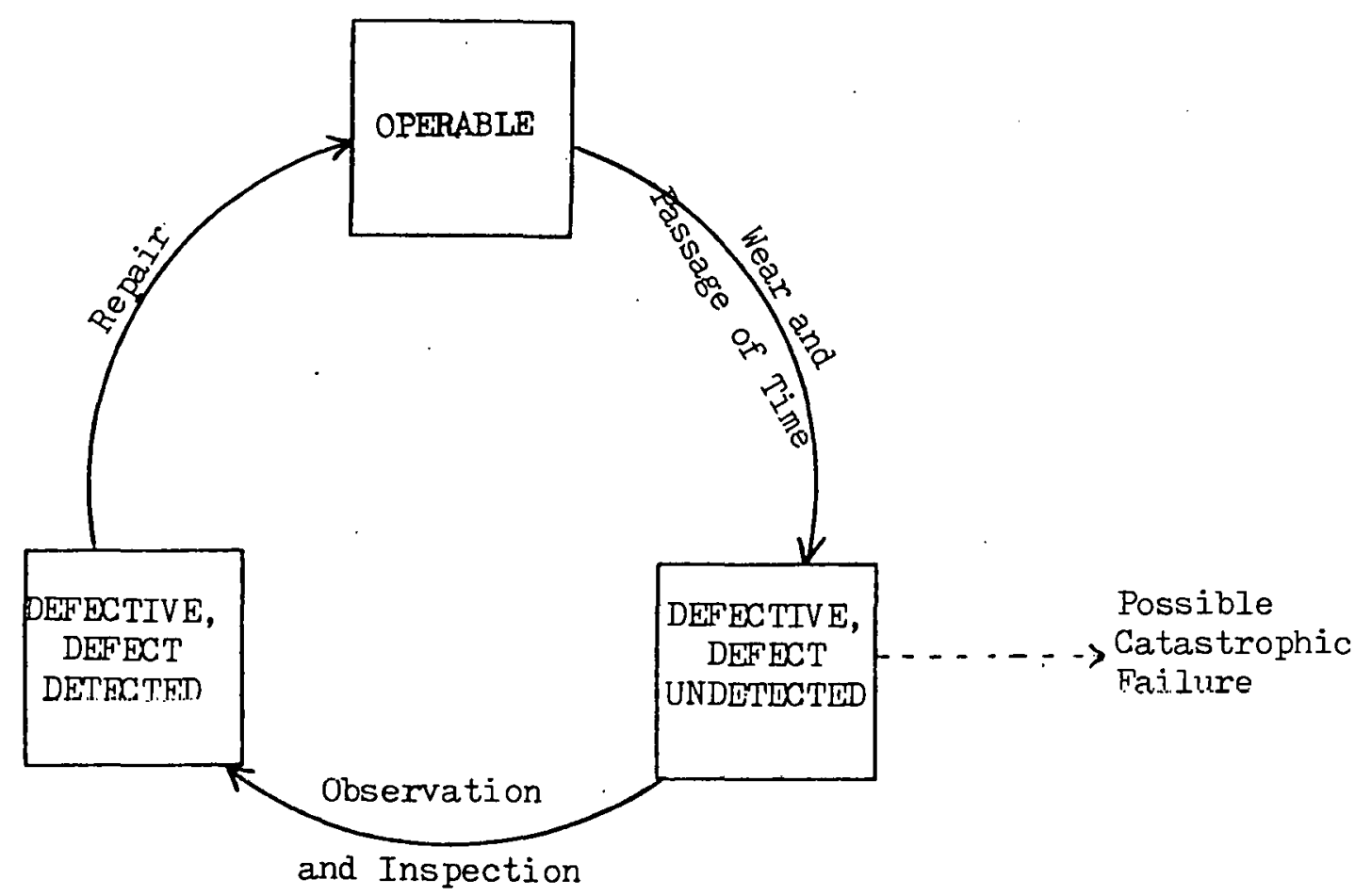

Figure 1-1. Ferforinance Cycle for Each Component

By identifying this intermediate state between Operable and Under Repair, we can calculate not only the system's reliability--i.e., its unavailability, or probability of being down for repairs--but also the probability of catastrophic failure due to undetected defects. 
The method so developed will be applied to determining the reliability and safety of a simplified wind energy conversion system. Work on wind energy conversion system reliability is nascent. A failure modes and effects analysis has been performed by Kaman Aerospace Corporation [4], and a systems analysis study has been completed in Canada for a large vertical axis wind turbine [5]. Analysis by General Electric on component failure modes was recently completed for the Mod-1 wind turbine [6]. Boeing has studied reliability and maintainability for the Mod-2 [7]. Calculations of system reliability and safety will surely be required as wind power moves toward commerclalization. 
SECTION 2.0

THE DEFECTIVE STATE

A component resides in the "Defective, But Defect Undetected" state if it is either

- operating substandardly and thereby degrading system performance (but not enough to occasion immediate detection),

- in danger of experiencing total failure (even if not currently degrading system performance), or

- tota11y failed, if a standby component.

We shall refer to the "Defective: But Defect Undetected" state as simply the "Defective" state.

There is some arbitrariness about the boundary between the Operable and Defective states. The threshold at which a component has degraded to the point of being called "substandard" is arbitrary. So is the point at which the danger of total failure becomes significant. We shall use as a working definition of the Defective state: a defect which would be identified, if detected during an inspection, as warranting nonroutine maintenance or repair. Crack development beyond a specified size is one example of defect development.

A component in the Defective state might experience total failure before its defectiveness is detected. The possibility of a component's going from defective to failed is a matter of concern only if failure of the component affects system safety. We shall refer to the total failure (as opposed to the defectiveness, or susceptibility to failure) of components affecting system safety as "catastrophic failure." A datum which will be required for such a component is its rate of catastrophic failure, given that it is defective. 
SER라

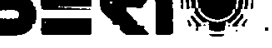




\section{SECTION 3.0}

\section{A SIMPLE EXAMPLE}

Consider a special automobile braking system, consisting of the usual foot brake and an independent emergency brake. Suppose that the rate of defect development (such as brake fluid leak) is once in five years for both brakes and that the rate of catastrophic failure, given that the brake is defective, is once in ten days. To restate, each brake can be expected to perform an average of five years before becoming defective and, once defective, can be expected to last ten days before failing completely.

The foot brake is used constantly. A defect like a brake fluid leak will be noticed fairly quickly. Assume an average time of one day until detection of this defect in the foot brake. The emergency brake, on the other hand, is used only as backup for the foot brake. A defect in the emergency brake will be discovered only during inspection, which takes place at regular four-month intervals. Thus, the expected time (in a probabilistic sense) until detection of a defect in the emergency brake is equal to the expected time until the next inspection, or two months.

Assume for this example that repair of either brake requires two days, but that inspections take negligible time.

The data for the two components of the braking system are given in Table $3-1$.

Table 3-1. BRARING SYSTEM DATA

\begin{tabular}{lcc}
\hline Parameter & $\begin{array}{c}\text { Foot } \\
\text { Brake }\end{array}$ & $\begin{array}{c}\text { Emergency } \\
\text { Brake }\end{array}$ \\
\hline Expected Time to: & & \\
Defect Development & 5 Years & 5 Years \\
Defect Detection & 1 Day & 2 Months \\
Repair & 2 Days & 2 Days \\
Total Cycle Time & 5.0082 Years & 5.1721 Years \\
Catastrophic Failure & & $1 /(10$ Days $)$ \\
Rate, Given Defective & $1 /(10$ Days $)$ & \\
\hline
\end{tabular}

It is apparent that the expected time to defect development is identical to the expected residence time in the Operable state. Further, the expected time to defect detection is the expected time in the Defective state and the expected time to repair is the expected time in the Repair state. Table 3-2 gives the state resldence probabilities which are normalized to the Total Syr le trime. 
Table 3-2. STATE RESIDENCE PROBABILITIES

\begin{tabular}{lcc}
\hline & $\begin{array}{c}\text { Foot } \\
\text { Brake }\end{array}$ & $\begin{array}{c}\text { Emergency } \\
\text { Brake }\end{array}$ \\
\hline Probability of : & & \\
Operable & 0.9984 & 0.9667 \\
Defective & 0.0005 & 0.0322 \\
Under Repair & 0.0011 & 0.0011 \\
\hline
\end{tabular}

Assume that, once defective, each brake is subject to a constant failure rate. This implies that the failure distribution is exponentlal, so that the probability of a failure of either brake within time $t$ in days after defect development is $1-\exp (-t / 10)$. Therefore, the probability that the foot brake will fail during its expected one day until defect detection is $1-\exp (-1 / 10)$ or 0.0952 . The probability that the emergency brake will fail during its expected 60 days (two months) until defect detection is 1 - exp $(-60 / 10)$ or 0.9975 .

We shall need to know the probability that each brake resides in the "catastrophically failed" state. If $T$ is the duration of residence in the defective state,* then the expected duration in the failed state is

$$
\begin{aligned}
& \quad T(T-t) \text { Pr \{failure occurs during time } d t\} \\
& \int 0 \\
& =\quad \frac{T}{0}(T-t) \frac{1}{10} e^{-(1 / 10) t} d t=T-10\left[1-\exp \left(-\frac{1}{10} T\right)\right]
\end{aligned}
$$

For the foot brake, $\mathrm{T}=$ one day. Therefore, the expected residence time in the failed state during one cycle is $1-10[1-\exp (-1 / 10)]=0.0484$ day or 0.00013 year. Since one cycle spans 5.0082 years (from Table 3-1), the probability that the foot brake is in the failed state is $0.00013 / 5.0082$ or $2.6 \mathrm{x}$ $10^{-5}$. Similarly, the probability. that the emergency brake is failed is

$$
\{60-10[1-\exp (-60 / 10)]\} /(5.1721 \cdot 365)=0.0265
$$

Table 3-3 shows the state residence probabilities of Table 3-2 expanded to include the probability of residence in the failed state. It also states the

*We have assumed in these calculations that the duration of residence in the Defective state is deterministic, although it is really a random variable. This approximation is warranted since some choice of a probability distribution must be made, and the one-point distribution--while unrealistic--is simplest and likely to produce as good an approximation as any other assumption. 
failure rates on a per year basis. These are all the data needed for the reliability and safety calculations.

Tab1e 3-3. STATE RESIDENCE PROBABILITIES EXPANDED TO INCLUDE FAILED STATE

\begin{tabular}{lll}
\hline & $\begin{array}{l}\text { Foot } \\
\text { Brake }\end{array}$ & $\begin{array}{c}\text { Emergency } \\
\text { Brake }\end{array}$ \\
\hline Probability of : & & \\
$\quad$ Operable & 0.9984 & 0.9667 \\
Defective & 0.0005 & 0.0322 \\
Under Repair & 0.0011 \\
Failed & $2.6 \times 10^{-5}$ & 0.0011 \\
Failure Rate, Given & $\cdots$ & 0.0265 \\
Defective (per year) & 36.5 & 36.5 \\
\hline
\end{tabular}

Catastrophic failure of the two-brake system occurs whenever one brake fails and the other has already failed. (Failure of both brakes at the same instant is an event with a vanishingly small probability.)

The probability that catastrophic failure occurs during the instant $\Delta t$ is therefore equal to

$\operatorname{Pr}\{$ foot brake failed $\} \cdot \operatorname{Pr}\{$ emergency brake defective

- (emergency brake failure rate) - $\Delta t$

$+\operatorname{Pr}\{$ emergency brake failed\} $\operatorname{Pr}$ \{foot brake defective

- (foot brake failure rate) - $\Delta t$

$=\left(2.6 \times 10^{-5} \cdot 0.0322 \cdot 36.5+0.0265 \cdot 0.0005 \cdot 36.5\right) \cdot \Delta t$

$=0.0005 \Delta t$

This implies that the probability of catastrophic failure of the braking system is about 0.0005 , or one in 2000, per year.

Note that a figure for unavailability of the system due to repairs may also be obtained from the data. The system is unavailable when either the foot brake or the emergency brake is being repaired. The probability is

$\operatorname{Pr}\{$ foot brake under repair\} + Pr\{emergency brake under repair\}

- Pr\{foot brake under repair\} - Pr \{emergency brake under repair\}

$=0.0011+0.0011-0.0011: 0.0011=0.0022$

Therefore the system is available $1-0.0022=0.9978$, or $99.78 \%$ of the time. of course, this is not meaningful in practice since components of the system other than brakes have not been considered. In a realistic example, all components of the system should be included in the availability calculation. 


\section{S린}

\section{4}


SECTION 4 -0

\section{GENERALIZED COAPONENT CALCULATIONS}

We now proceed to the calculations for the general case.

The inputs required for each component of the system are as follows:

$\mathrm{T}_{0}$, mean time to defect development (in years)

$\mathrm{T}_{\mathrm{f}}$, expected time (in days) until catastrophic failure, given that component is operating defectively (required only if component failure affects system safety)

$N_{i}$, frequency of inspections of this component (number per year)

$\mathrm{H}$, time in man-hours required to inspect this component

Q, probability of detecting an existing defect during an inspection

$C_{i}$, inspection cost in dollars allocable to this component

$t_{d}$, mean time to defect detection (in days), if less than time until next inspection

$\mathrm{T}_{\mathrm{r}}$, mean time to repair (in days)

$C_{r}$, average cost in dollars to repair/replace this component

Also required is $\mathrm{W}$, the number of workers on the inspection and maintenance team (this input is system-specific, not component-specific).

The duration of an inspection is

$$
\frac{\mathrm{H}}{8 \mathrm{~W}}(\text { days })=\frac{\mathrm{H}}{8 \mathrm{~W}} / 365,(\text { years })=\frac{\mathrm{H}}{2920 \mathrm{~W}}(\text { years })
$$

assuming an 8-hour work day.

Therefore,

$$
\text { time between inspections }=\frac{1}{N_{i}}-\frac{H}{2920 \mathrm{~W}} \text { (years). }
$$

If a component is currently in the operating mode (either Operable or Defective), then the expected time until the next inspection is

$$
\frac{1}{2}\left(\frac{1}{N_{i}}-\frac{H}{2920 W}\right)
$$


If the component is defective but the defect is not discovered until the ( $\mathrm{k}+$ 1)'st inspection, then the operating time until detection is

$$
\frac{1}{2}\left(\frac{1}{N_{i}}-\frac{H}{2920 W}\right)+k\left(\frac{1}{N_{i}}-\frac{H}{2920 W}\right)=\frac{1}{2}\left(\frac{1}{N_{i}}-\frac{H}{2920 W}\right)(2 k+1) .
$$

The probability that a defect is discovered during the $(k+1)$ 'st inspection, but not until then, is $Q \cdot(1-Q)^{k}$. Therefore, the expected operating time unt11 a defect is discovered by inspection is

$$
\frac{1}{2}\left(\frac{1}{N_{i}}-\frac{H}{2920 W}\right) Q \sum_{k=0}^{\infty}(2 k+1)(1-Q)^{k}
$$

which equals

$$
\frac{2-Q}{2 Q}\left(\frac{1}{N_{i}}-\frac{H}{2920 W}\right) \text {. }
$$

The expected time until defect detection, however, may be less than the expected time for a defect to be found through inspections. The input, $t d$, is provided to cover this eventuality. For example, the defective foot brake is discovered not through shop inspections but through observation of its behavior in use. To summarize, the expected time $\mathrm{T}_{d}$ in years until defect detection is expressed by

$$
\mathrm{T}_{\mathrm{d}}=\operatorname{minimum}\left[\frac{2-\mathrm{Q}}{2 \mathrm{Q}}\left(\frac{1}{\mathrm{~N}_{\mathrm{i}}}-\frac{\mathrm{H}}{2920 \mathrm{~W}}\right), \frac{\mathrm{t}_{\mathrm{d}}}{365}\right] \text {. }
$$

The Inspection time as a fraction of the nominal operating time (i.e., all but the time down for repairs) is

$$
\mathrm{f}=\frac{\mathrm{H}}{2920 \mathrm{~W}} / \frac{1}{\mathrm{~N}_{\mathrm{i}}}=\frac{\mathrm{N}_{\mathrm{i}} \mathrm{H}}{2920 \mathrm{~W}} \text {. }
$$

Then the elapsed time which is actually spanned by the first two states of the component's cycle (Operable and Defective), when time down for inspections is included, is $\left(T_{0}+T_{d}\right) /(1-f)$.

Letting $\mathrm{T}_{i}=$ inspection and maintenance time during component cycle,

$$
\mathrm{T}_{i}=\left(\mathrm{T}_{\mathrm{o}}+\mathrm{T}_{\mathrm{d}}\right) /(1-\mathrm{f})-\left(\mathrm{T}_{\mathrm{o}}+\mathrm{T}_{\mathrm{d}}\right)=\frac{\mathrm{f}}{1-\mathrm{f}}\left(\mathrm{T}_{\mathrm{o}}+\mathrm{T}_{\mathrm{d}}\right) \text {. }
$$

Letting $T_{c}$ be the time required to complete one component cycle,

$$
\mathrm{T}_{\mathbf{c}}=\mathrm{T}_{\mathrm{o}}+\mathrm{T}_{\mathrm{d}}+\mathrm{T}_{\mathrm{i}}+\mathrm{T}_{\mathrm{r}_{\mathrm{p}}}
$$


The associated state residence probabilities are

$$
\begin{aligned}
& P_{o} \equiv T_{o} / T_{c} \\
& P_{d} \equiv T_{d} / T_{c} \\
& P_{i} \equiv T_{i} / T_{c} \\
& P_{r} \equiv T_{r} / T_{c} .
\end{aligned}
$$

The fallure rate of the component, given that it is defective, is

$$
\lambda=365 / \mathrm{T}_{\mathrm{f}} \text { per year }
$$

and the probability of residence in the failed state is

$$
P_{f}=P_{d}-\frac{1-e^{-\lambda T} d}{\lambda T_{c}} .
$$

The expected inspection and maintenance cost per year is

$$
\mathrm{C}_{i} \mathrm{~N}_{\mathrm{i}}\left(\mathrm{T}_{\mathrm{o}}+\mathrm{T}_{\mathrm{d}}+\mathrm{T}_{\mathrm{i}}\right) / \mathrm{T}_{\mathrm{c}}
$$

and the expected repair/replacement cost per year is $C_{r} / T_{c}$.

The above calculations assumed that the component is not operating during inspections or repairs. It is easy to adjust the calculations for cases when these assumptions are not true. These adjustments are incorporated as options in the computer program 11sted in Appendix B. 
SERP蕃 


\section{SECTION 5.0}

\section{GENERALIZED SYSTEM CALCULATIONS}

A generalized system is described through its minimal path sets and minimal cut sets. A "path set" of a system is a set of components such that, if all are in working order, then the system is in working order. A minimal path set is a path set such that no proper subset is a path set. Obviously, any component which is not in a specified minimal path set can be labeled redundant. A "cut set" of a system is a set of components such that, if all are not in working order, then the system is not in working order. A minimal cut set is a set of components such that no proper subset is a cut set.

If all the minimal path sets of a system are specified, then the minimal cut sets can be derived and vice versa [ 8]. Nevertheless, the computer program listed in Appendix B requires both minimal path sets and minimal cut sets as input. An algorithm deriving one from the other could be added easily as a front end to the program. However, it is a useful exercise in qualitative analysis of the system for the program user to list both the system's minimal path sets and minimal cut sets.

The system reliability and safety calculations to be presented are based on the assumption that the performance cycles of the components in the system are independent of one another. For example, the time to defect development of component $A$ is assumed to be independent of the time to defect development of component $B$, and the time to repair component $A$ is assumed to be independent of the time to repair component B. This is an assumption which may not apply to some systems. Care should be taken to consider the possible invalidity of this assumption before applying the methodology.

We shall describe in detail the calculation of two system statistics: the probability of the system's being down for inspection and maintenance or repairs (i.e., system unavailability), and the probability of catastrophic failure (i.e., system safety). Other statistics--the probabilities of normal and defective system operation and the annual inspection and repair costs--also are computed in the Reliability and Safety Program listed in Appendix B. (See Appendix A for sample output.)

System unavallability, the probability of being down for inspection or repair, is easily calculated. The probability that the system is down due to inspection or repair of some component is the probability of the union over all $k$ of the events \{component $k$ is undergoing inspection or repairs\}.* Let $r_{k}=P_{1}+$ $P_{r}$ for the $k^{\prime} t h$ component. The probability of a union of events can be computed from the probabilities of the events themselves by means of an elementary law of probability (see, for example, [9], page 27) sometimes called the General Law of Additinn. Thus, the probability of system unavailability for a system of $m$ components is

*Assuming the system is shut down whenever any component is undergoing inspection or repair. The program in Appendix B relaxes this requirement. 


$$
\sum_{k} r_{k}-\sum_{j \neq k} r_{j} r_{k}+\sum_{i \neq j \neq k} r_{i} r_{j} r_{k}-\ldots+(-1)^{m+1} \underset{k}{\prod_{k}}
$$

To compute the rate of system catastrophic fallure, we first note that system fallure will be determined by some sequence of component failures. Any one of the components may be the last to fail.

Suppose that the $k^{\prime}$ th component is the last to fail. System failure due to fallure of. the $k^{\prime}$ th component will occur during the instant $\Delta t$ if:

(1) A11 the other safety-related components in some cut set to which component $k$ belungs have alreädy failed.

(2) Component $k$ is defective (hut. not failed).

(3) Component $k$ passes from defective to falled in the subsequent instant $\Delta t$.

Let the minimal cut sets contalning component $k$ be designated $s_{1}, \ldots, s_{N}$, and

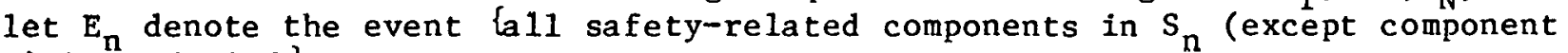
k) have falled .

Letting $q_{j}=P_{f}(j)=$ the probability that component $j$ is in the failed state (= 1 if component $\mathrm{j}$ does not-contribute to system safety),

$$
\operatorname{Pr}\left(E_{n}\right)=\prod_{j}^{j \notin S_{n}} q_{j}
$$

The probability that all of the safety-related components except component $k$ have failed in at least one of the cut sets $s_{1}, \ldots, s_{N} l f \ldots .$, that event (1), above, occurs $\mid$ is $\operatorname{Pr}\left(E_{1} U E_{2} U \ldots U E_{N}\right)$. But by the General Law of Addition we have

$$
\begin{aligned}
& \eta_{k}=\operatorname{Pr}\{\text { cuent }(1)\}=\operatorname{Pr}\left(E_{1} U_{2} E_{2} \ldots E_{N}\right)
\end{aligned}
$$

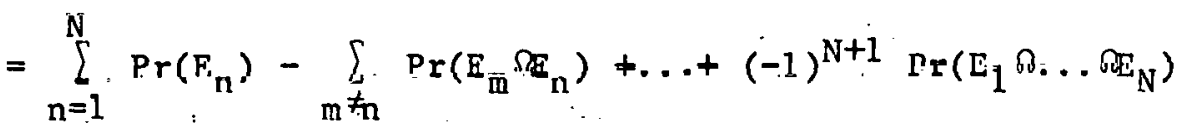

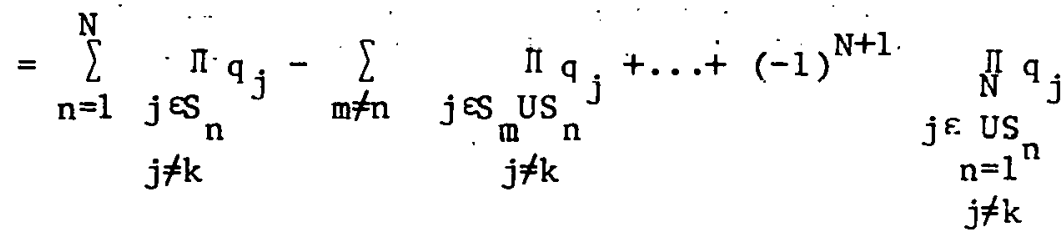

The probability that events (2) and (3) occur is 


$$
\left[\mathrm{P}_{\mathrm{d}}(\mathrm{k})-\mathrm{P}_{\mathrm{f}}(\mathrm{k})\right] \lambda(\mathrm{k}) \Delta \mathrm{t} \text {. }
$$

Hence, the probability that events (1), (2), and (3) occur is

$$
\rho_{k}\left[P_{d}(k)-P_{f}(k)\right] \lambda(k) \quad \Delta t \text {. }
$$

The probability that catastrophic system failure occurs during time $\Delta t$ is simply the sum of these probabilities over all components $k$. Letting $\lambda_{S}$ be the rate of catastrophic system failure, so that $\lambda_{S} \Delta t$ is the probability of catastrophic system failure during the instant $\Delta t$, we have

$$
\lambda_{\mathrm{S}}=\sum_{\mathrm{k}} \rho_{\mathrm{k}}\left[\mathrm{P}_{\mathrm{d}}(\mathrm{k})-\mathrm{P}_{\mathrm{f}}(\mathrm{k})\right] \lambda(\mathrm{k})
$$

The mean time to system catastrophic. failure is then $1 / \lambda_{S}$, and the probability of catastrophic failure in a single year can be assumed to be $1-\exp \left(-\lambda_{S}\right)$, or approximately $\lambda_{S}$ (if $\lambda_{S}$ is sma11). 
SEPI竭

16 
SECTION 6.0

\section{A SIMPLIFIED WIND ENERGY CONVERSION SYSTEM EXAMPLE}

The general methodology described in the previous section is capable of treating systems containing many components. One reason for developing the methodology was for use in analyzing the reliability and safety of wind energy conversion systems.

A recently reported wind turbine accident involving the collapse of a $150 \mathrm{ft}$ vertical axis machine was, in fact, closely related to one component, a set of drag brakes, having been in the "Defective, Defect Undetected" state [10]. Similar undetected defects seem to have been responsible for the collapse of several small wind turbines. While many of these problems have been due to lack of quality control in the production of research and demonstration machines, the possibility of wind turbine catastrophic fallure is not insignificant. The following examples are falrly realistic but are simplified considerably to illustrate the methodology's application.

Figure 6-1 diagrams a skeleton wind energy conversion system (WECS). Note that this is a highly simplifted version of a WECS, including no pitch-control or yaw-control mechanisms. Furthermore, a large or sophisticated WECS will include many auxiliary safety devices such as vibration, loss of line voltage, overspeed, and other. critical parameter sensors.

The WECS diagrammed in Fig. 6-1 has on 1 y a braking system to control the rotor. The primary brake is the disc brake, which is applied to the shaft of the rotor. The drag brake, which serves as backup, is located near the outer extremities of the rotor and extends to offer alr resistance against the rotor's angular momentum. The fallure probability of such a system has been analyzed previously using conventional electric power systems reliability methods [5].

Modes of catastrophic failure of this system are:

- both brakes fa1l, resulting ln an uncontrollable rotor; or

- the rotor falls catastrophically of 1ts own accord--1.e., breaks and collapses.

The gear box and generator can become defective also, but we can assume that their defectiveness will not pose a safety hazard. Their defectiveness, however, will have a negative effect on system performance. As a result, the defectiveness of elther gear box or generator would probably be discovered simply through observing the system performance over time.

As the above discussion implies, the cut sets of this system are:

- rotor;

- diac brake and drag brake; 


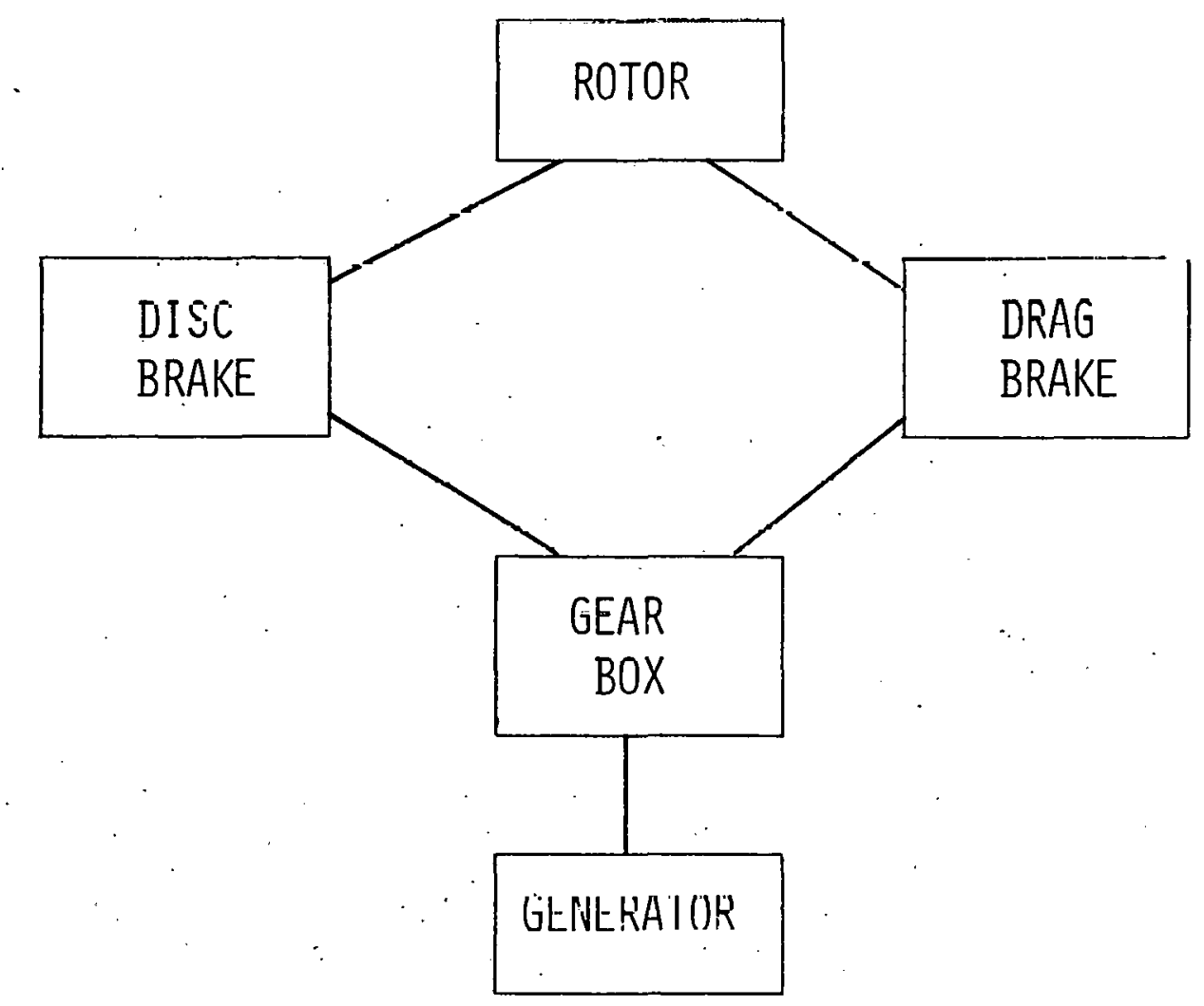

Figure $6-1$. SIMPLIFIED WIND ENERGY CONVERSION SYSTEM 
- gear box; and

- generator.

That 1s, the system is operating defectively (or in danger) if all the components in one of these four sets are Defective.

The path sets of the system are:

- rotor, disc brake, gear box, and generator; and

- rotor, drag brake, gear box, and generator.

That is, the system is operating normally (1.e., it is safe and performance is not degraded) as long as all the components in one of these two sets are Operable.

Appendix A shows the output of the Reliability and Safety Program (RASP) for this example. Pages $\mathrm{A}-2$ and $\mathrm{A}-3$ list the component inputs which were used. Page A-4 lists the minimal path sets and minimal cut sets that were input. These inputs were chosen in order to represent as realistically as possible those of a real wind energy conversion system, but they are still 1llustrative.

Page A-7. gives the system outputs. The probability of a catastrophic failure as calculated by Eqs. 2 and 3 is 0.012 per year in this example, and the mean time to catastrophic failure is 81.4 years. The unavailability due to maintenance or repairs (Eq. 1) is $1.3 \% .4 .2 \%$ of the time the system will be operating but defective. Thus the system is available for normal operation $94.5 \%$ of the time. The cost of maintenance and repairs averages about $\$ 3900$ per year. These numbers are probably reasonable for a wind turbine of intermediate size, but note that other protection devices, such as pitch and yaw controls on a horizontal axis wind turbine, have not been included.

The subsequent tables on pages $A-7$ and $A-8$ show the effect of improving each of the components, either by increasing its mean time to defect development, by decreasing the time to defect detection, or by decreasing the time to repair. For example, on page $A-7$ it is shown that increasing the mean time to rotor defect development by $50 \%$ increases the mean time to system fallure by $43.5 \%$. On the other hand, increasing the mean time to defect development for either brake has a much smaller impact on system safety. This shows clearly that the rotor is the most safety-critical component. If maintenance and repair costs are a concern, however, improvement of the drag brake will have the most favorable impact $(-7.79 \%)$. Such sensitivity calculations provide valuable input to a design-to-cost project, in which the systems engineering of a wind energy conversion system is optimized while the system cost is minimized.

As an improvement to the system, let us consider the addition of a crack sensing device which would detect major cracks developing in the rotor blades. Flgure 6-2 diagrams the system with this addition. Only system safety 1s being considered so the gear box and generator are irrelevant and are shown in dashed lines.

The crack sensor will be attached so as to activate the disc brake if a major crack is sensed. 


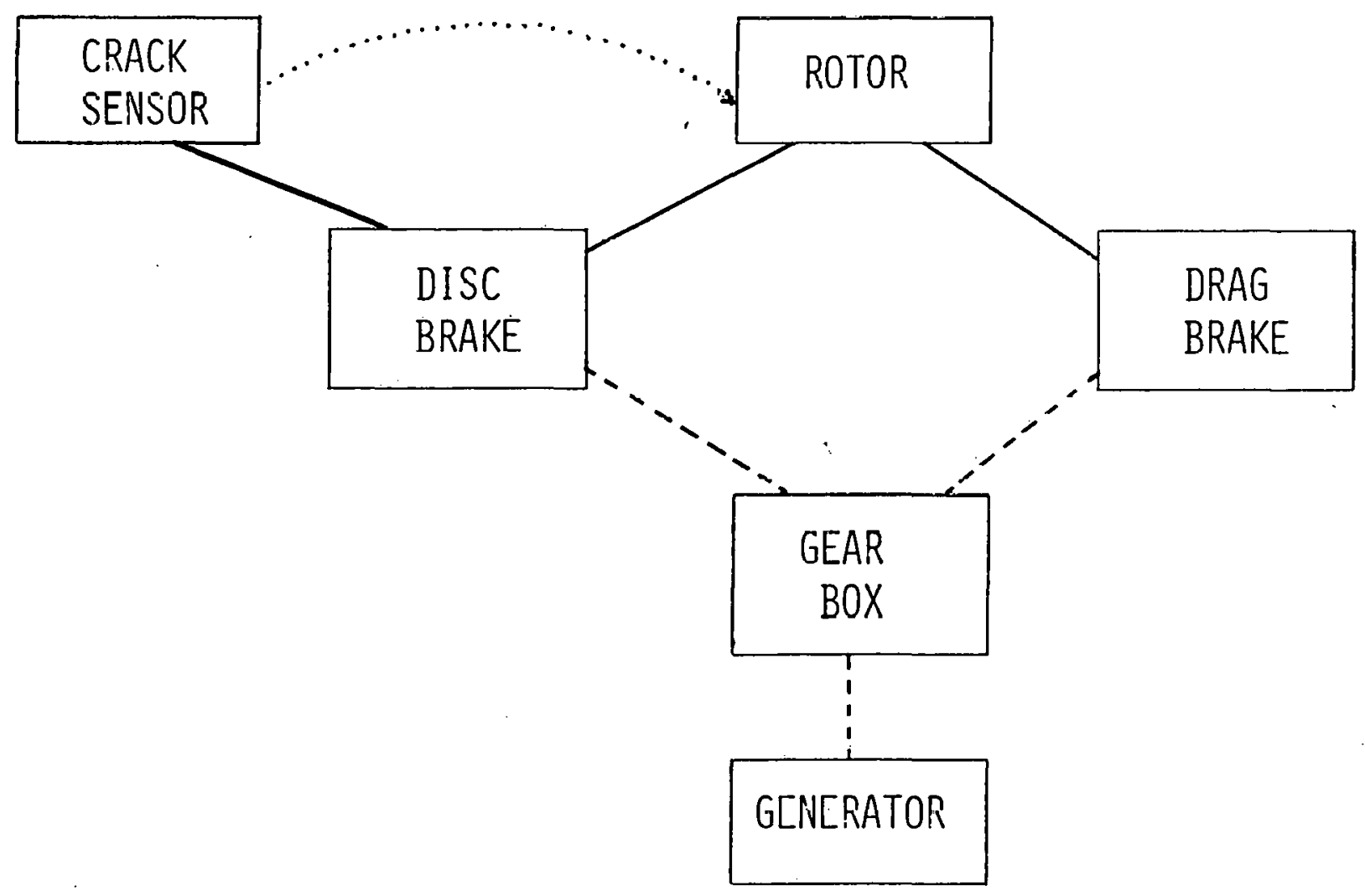

Flgure 6-2. SIMPLIFIED WIND ENERGY CONVERSION SYSTEM WITH CRACK SENSOR 
For the objective of system safety, the cut sets become:

- rotor and crack sensor (because if the rotor becomes defective and the crack sensor is not working then the system is in danger);

- rotor and disc brake (because if the rotor becomes defective and the disc brake is not working then the crack sensor has no means to stop the rotor); and

- disc brake and drag brake (as above).

The fact that the crack sensor is a rather unreliable device is expressed by its being assigned a one-year mean time to defect development (which we sha11 assume is followed immediately by or is synonymous with failure). Assume the crack sensor is inspected four times a year, but that the probability of detecting and correcting a lefect is only 0.8 .

The result of recunning RASP with the crack sensor included is that the probability of catastrophic system failure becomes 0.0044 , about three times less than that of the system without the crack sensor.

The above example shows how system reliability and safety projections can be made when data on component defect development and failure rates are available. It cannot be emphasized enough that component failure rates are often unknown or highly uncertain. This is the case, for example, for the rotor in a large wind turbine. Additional testing and experience will make better component failure rates available, which will improve the meaningfulness of system reliability and safety estimates. Even in the absence of good component failure rate estimates, however, the Reliability and Safety Program can compare different system designs to determine their relative reliability and safety. 


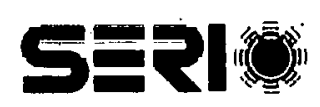




\section{SECTION 7.0}

\section{CONCLUSION}

The methodology embodied in the Reliability and Safety Program can be used to determine both system availability and the probability of catastrophic system fallure. By investigating the sensitivity of these statistics to changes in the reliability of individual components, the methodology can identify. critical components, thereby aiding in decisions relating to inspection and maintenance schedules, durability of various components, and system redundancies. Although the program was developed for wind energy conversion systems, it is a general one and would be useful for any system for which reliability and safety are major concerns. 
SERI 


\section{SECTION 8.0}

\section{REFERENCES}

1. Billinton, R.; Ringlee, R. J.; Wood, A. J. Power System Reliability Calculations. Cambridge, MA: M.I.T. Press; $197 \overline{3}$

2. Billinton, R. Power System Reliability Evaluation. Gordon and Breach; 1970 .

3. Ha11, J. D.; Ringlee, R. J.; Wood, A. J. "Frequency and Duration Methods for Power System Reliability Calculations: I - Generation System Mode1." IEEE Transactions on Power Apparatus and Systems. Vol. PAS-87 (no. 9): pp. 1787-1796; September 1968 .

4. Kaman Aerospace Corporation. "Design Study of Wind Turbines 50kW to $3000 \mathrm{~kW}$ for Electric Utility Applications." DOE Report No. DOE/NASA/940476/2, Appendix C; February 1976.

5. Fortin, M. "Etude de Fiabilite, Systeme de Freinage, Eolienne des Iles de la Madeleine." Unpublished report, Institut de Recherche de 1'HydroQuebec, 1977. (In French)

6. Genera1 Electric Co. "Mod 1 Wind Turbine Generator Failure Modes and Effects Analysis." DOE Report No. DOE/NASA/0058-79/1; February 1979.

7. Boeing Engineering and Construction. "Wind Turbine System Mod-2 Project: - Reliability, Maintainability, Logistics; Detail Design Review." May 15, 1979.

8. Kaufman, A.; Grouchko, D.; Cruon, R. Mathematical Models for the Study of the Reliability of Systems. Academic Press; 1977 .

9. Hickman, Edgar P.; Hilton, James G. Probability and Statistical Analysis. Intext Educational Publishers; 1971.

10. Templin, R. J.; McConne11, R. D. "Summary Report on the Collapse of the Magdalen Islands Wind Turbine." Proceedings of the Workshop on Economic and Operational Requirements and Status of Large Scale Wind Systems. EPRI ER-IIIO-SR, p. 353; July 1979. 


\section{SझR1}




\author{
APPENDIX A \\ Output of \\ Reliability and Safety Progran \\ for \\ Simplified Hind Energy Conversion System Example
}

A-1 


\section{SIMPLIFIED SKELETDM WIMI ENERG'Y LONWERSIOH SYSTEM}

FUNACTIUN: PELIABLE ANI SAFE DPERATIUN

\begin{tabular}{|c|c|c|c|}
\hline CDMPUNENT: & $\begin{array}{c}1 . \\
\text { RATIR }\end{array}$ & DISC BRAKE & DFEA 3. \\
\hline $\begin{array}{l}\text { MEAN TIME TO DEFECT } \\
\text { DEVELOPMENT CYEARS: }\end{array}$ & 20.010 & 5.00 & 5.00 \\
\hline $\begin{array}{l}\text { IDES FAILURE FFFECT } \\
\text { SYSTEM SAFET'Y? } \\
\text { CI=YES, } 0=N D:\end{array}$ & 1 & 1 & 1 \\
\hline $\begin{array}{l}\text { EXP. TIME IH DAYS TD } \\
\text { CATASTRDFHIC FAILURE, } \\
\text { GIVEN DEFECTIVE }\end{array}$ & 1000.00 & 10.00 & 10.00 \\
\hline $\begin{array}{l}\text { IOES FAILURE CAUSE } \\
\text { IMMED. SYSTEM FRILUFE? }\end{array}$ & 1 & 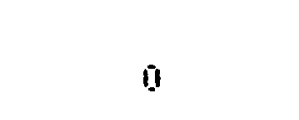 & 0 \\
\hline $\begin{array}{l}\therefore \text { IF INSPECTIUNS DF } \\
\text { THIS COMPUNENT FER YR. }\end{array}$ & 1.00 & 1.00 & E. \\
\hline $\begin{array}{l}\text { TIME REQD. TD INSPECT } \\
\text { IN MAN-HQURS }\end{array}$ & 16.00 & 4.00 & 4.00 \\
\hline $\begin{array}{l}\text { PRAB. DF DETECTINF NF- } \\
\text { FECT DUURINE INSFECTIDN }\end{array}$ & . 80000 & .9000 & 1. घแบแแ \\
\hline $\begin{array}{l}\text { SYSTEM SHUT IUUN } \\
\text { DUPING IMSPECTIDH? }\end{array}$ & 1 & 1 & 1 \\
\hline $\begin{array}{l}\text { COMPOMENT IPERAELE } \\
\text { DIJRINIE IMSPECTIONT }\end{array}$ & 0 & 0 & 0 \\
\hline INSPECTIUNA EQST IN $B$ & 1000.00 & 250.001 & 850.010 \\
\hline $\begin{array}{l}\text { MEFN TIME TQ DEFECT } \\
\text { DETEETION CIAYYS }\end{array}$ & -1.00100 & 1. yong & -1.0001 \\
\hline $\begin{array}{l}\text { MEFAY TIME TD PEFAIF } \\
\text { UIATS }\end{array}$ & 7.00 & 1.90 & 7.010 \\
\hline 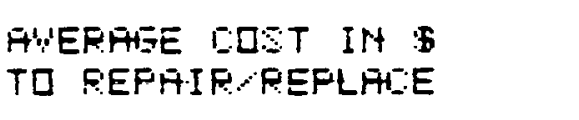 & 5000.001 & 10100.800 & somo. \\
\hline $\begin{array}{l}\text { OSTEM SHLIT DOUNA } \\
\text { DUIFINIG REPAIFT }\end{array}$ & 1 & 1 & 1 \\
\hline
\end{tabular}




\section{EDMPOFHENT:}

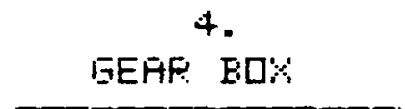

20.

9

1]

\begin{abstract}
MEAN TIME TD DEFECT
IEVELDFMENT OVEAFS

DOES FAILLIFE RFFEET

YSTEM SAFETYT

$C 1=Y E S, D=H O$

E\%P. TIME IN IIAYS TO

EATASTPOFHIE: FAILURE.
\end{abstract}

EIYEN IIEFEITTIVE

IIDES FAILIIFE EAISE

IMMED. SYTEM FAILUFE?

1.1. 010

0. 10

0

0

* DF INSFECTIOHA DF

THIS LOMPORENT FER YR.

1. 111

1.

TIME PEBII. TO IMSPEIT

IN MAH-HOUFS

FPOE. OF IIETECTINI IIE-

FEITT DIIFIMG INAFECTILH

$$
\text { 4. }
$$

4. 10

OSTEM SHITT DOLNA

IUUF:IHE IMSEETIDH?

BOMFOHAEHT OFERAFLE

IIIIFIHIS INAFECTIDIT

IHSFETIOH EQST IH I

MEAHY TIME TD IIEFEI:T

IIETEETION IIATS

MEFHA TIME TO FEFAIP

IIFYS

A'WEPAEE ROST IN TH

TO FEPAIF FEPLAIEE

OUTEM SHIST TULUH

IIIIFIIHE REFHIF?

$$
\text { - } 9 \text { Inia }
$$

- Fogna

1

1

1

10

250.010

30.0000

:30 -

7.011

7.010

301010

1
3010.99 


\section{MINIMAL FATH SETS}

RUTDR

DISC BRAKE

GENR DOK

GENERATDR

RQTOR

DRAG BRAKE

GEAR HDX

GEMERATDR

MINIMAL CUT SETS

RDTDR

DISC BRAKE

IURATE BFIFKE

GEAF: $D O X$

GENERATDR 


\section{EXPECTED STATE RESIDENIE DURATIONS \\ FOR INDIYIIJIFL EDMFURENTS}

CIN 'IEARS?

$c$

ROTOP

IISC BRAKE

IPTIE BRAKE

GEFR BDX

GENERTTTRR
MORMAL DPERATION

20. Dogna

5.0010010

5.001000

20.

25.000010

\begin{tabular}{l} 
DEFECTIVE \\
DFERATION \\
\hline .74795 \\
.00274 \\
.24956 \\
.08219 \\
.03219
\end{tabular}

REPAIR

01919

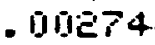

.01913

.01913

.01913
INSPECTION : MAIHTEMATHE

- 01074

- $\sin \sin$

- 0 ongs

.00063

- $0010 \sin$

STATE PESIDENIE PROEAEILITIES

FOP INIIUIDUAL COMPONENTS

FDTQF:

IIST ERATEE

ITPETE BFIFE

BEFF BQ:

EENEFATAF
DFEFATIIIA

.90102

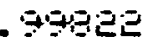

.9478

.9403

.94506
DIEFECTI YE
DFERAT I UH'

PEPAIR

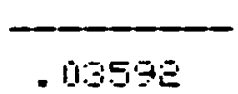

- 01055

.04732

.011010

. ด198\%

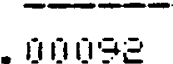

.00055

. 01089

- niings

- 1078
IHSFEETIDH : MAINTENATHCE

- Mn:74

- Mingia

. 00135

- Dins

. 00068 
MAINTEMANIE FNI REPAIR COSTS G FEP YEAFS

RATQP.

DISC EPARE

DIPAD BRAKE

BEAF BU:

BETEFTATAP

TITAL MUTEM EDSTS
INSPECTION \&

MAINTENAHTIEE

594.19

249.55

498.13

巳4宁宁

249.51

ت己+5
REFAIF DP.

REFLRT:EMENT

2411.11

199.84

947.83

147.14

119.43

1556.91
35.34

TOTAL

1239.19

449.51

$1+45$

393.919

므. 7 
SIMPLIFIED SKELETDN WIND ENERG'Y EOHWEFSIUH SYSTEM

FIJMETIOH: RELIABLE ANI SAFE DFERATIOH

SYSTEM AWAILABILITY

UNAVAILABILITY DIIE TD MAINTENANIEE FND FEPAIPS

PERCENTAEE DEFECTIYE DF SUE-STAHDARD DPERATIUH

mean. time to chtastrofhic failuae

PROBAEILITY' DF GATASTROPHIE FAILIJPE.

EQST DF MAINTEMAMIEE FANI PEPAIRS CW
94. 5 FERTENT

1.3 FEREENT

4. I FEREENT

31. 4 YEARS

- 1EE-MI FER 'TEAR.

3912.70 PER YERP

SEMSITIUITIES TQ $5 \Pi$ FITT. INEREASE IN MEAN TIME

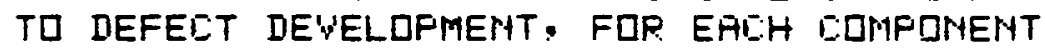

CHATIEE IH:

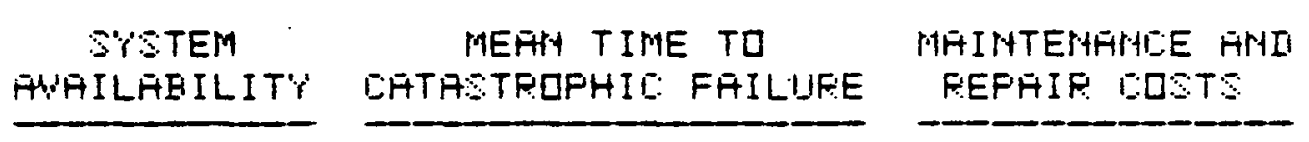

RATQR

1.255 PET

4.5 .50 PET

-1.95 FET

DISE BPAKE

.041 PET

ㄹ. 23 PET

-1.7I FET

IIPATE EPATKE

$.15 \mathrm{FET}$

2. 15 PET

-7.79 FET

GEFP BC\%

. 1 BII FET

D. 010 PET

-1.ET FET

BETHEFATDF:

$.14 \%$ PET

1. $011 \mathrm{FET}$

-1. IIE PET 
SEMSITIUITIES TQ 50 FET. DECREFAE IM MEFM TIME

TD DETECT DEFECT. FER. EATEH GOMFIMENT

\section{CHANEE IN:}

\begin{tabular}{|c|c|c|}
\hline $\begin{array}{l}\text { SYSTEM } \\
\text { AWAILFEILITY }\end{array}$ & $\begin{array}{l}\text { MEAN TIME TD } \\
\text { GATASTRUPHIE FAILUEE }\end{array}$ & $\begin{array}{l}\text { MAINTENANAE FMII } \\
\text { PEPAIR GQSTS }\end{array}$ \\
\hline 1.457 PET & 1434.51 PET & . DG FET \\
\hline-.1153 FLT & S.5+ PET & -.00 FLT \\
\hline-.142 FIT & 2.90 PLT & .55 PET \\
\hline - 129 PET & 0.00 PET & .DI FET \\
\hline TET & 0.00 FET & . DIO FET \\
\hline
\end{tabular}

SEMSITIYITIES TQ 50 PLT. DECREATE IN PAEAH TIME

TU FEPATIR. FOR ERTLH DOMFURIEMT

\begin{tabular}{|c|c|c|}
\hline PUTAR. & 1.459 PET & $1434.51 \mathrm{PET}$ \\
\hline DISC ERATE & $-.115 \%$ FLT & $5.5+$ PET \\
\hline DRAE BRIKE & -.142 FITT & 2.90 PLT \\
\hline GEAP BUK & . 129 PET & 0.00 PCT \\
\hline BEMEPATQR & . 050 FET & $0.00 \mathrm{FET}$ \\
\hline
\end{tabular}

GHFMEE IN:

PITUF

DISD BFAKE

IFAR BFAKE

GETP SC\%

GEMERTETE
STTEM F'A AILABILITY

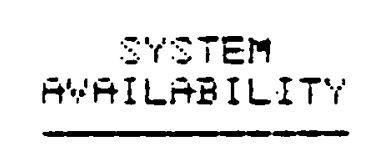

.042 PITT

. DES FET

- DiE PET

- DISE FET

.000 FET
MEAN TIME TJ EATASTPQFHIE FAILIIFE

MAINTERARHE BHII FEFAIE GOST

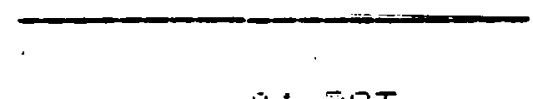

$$
\text { -. DI: FET }
$$$$
\text { - DII FET }
$$$$
\text { -.01 FET }
$$

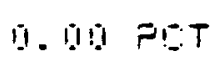

a. 019 FET
- II FET

- DII FET

- DT Fi:

. 00 ELT

- 010 FET 


\section{AP PENDIX B \\ Listing of \\ Reliability and Safety Progran (RASP)}




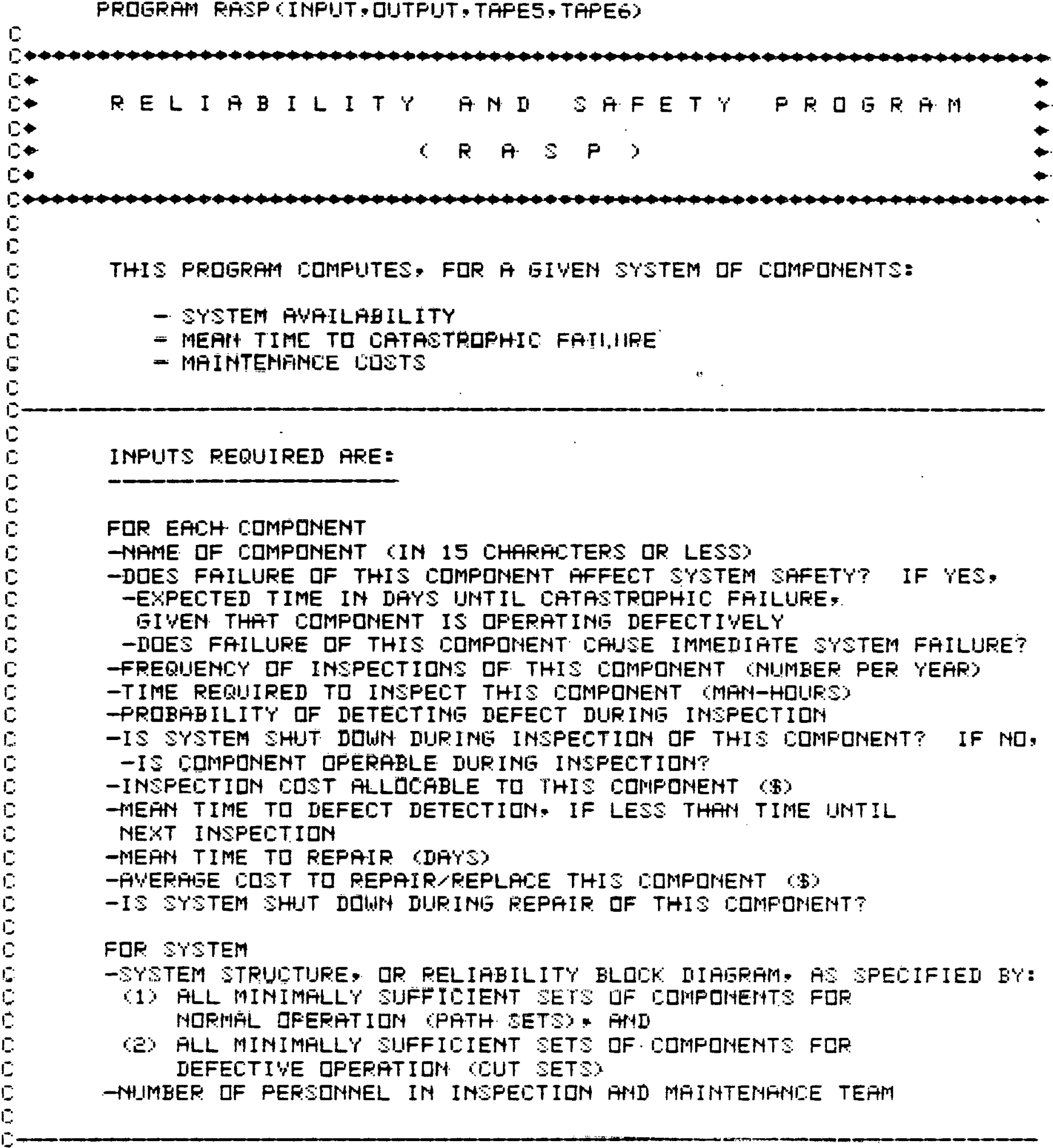




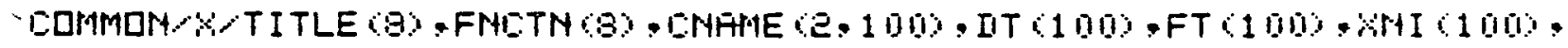

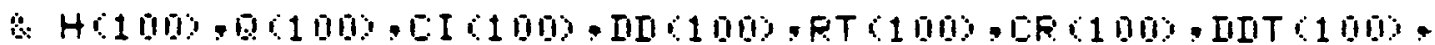

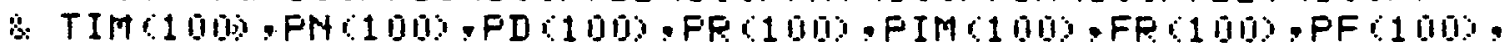

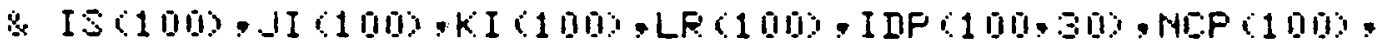

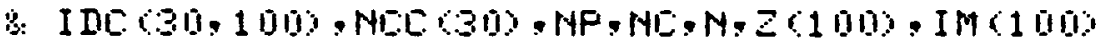

IIATA INADי" -

FEAD IN THAME DF SYSTEM FUR THIS RLIH FEAD 10.TITLE

11) FURMAT SBA10?

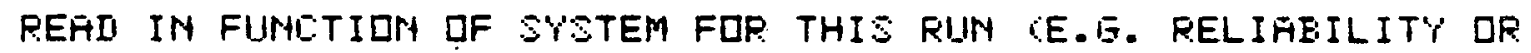
SAFETY QR: FOTHY

PEAD 10. FNLTN

E

FEAE MIMPER DF DIFFERENT COMPOHEMTS IM SYSTEM UIF TO 100 READ 20.NA

ZI FUFMAT (I3)

E

E READ COMFONENT INPUTS FDR EAEH COMPOMENT

E CODMPUNENT I.D. HUMBERS WILL EE ASSIBMEI IM IMPIT DFIEFO

DO $30 I=1, N$

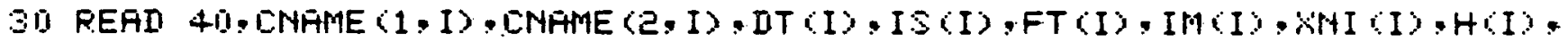

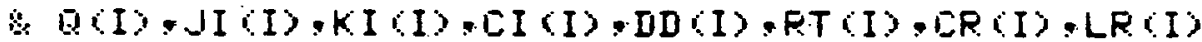

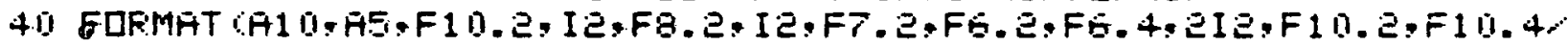

: $E F 10.2, I Z$ ?

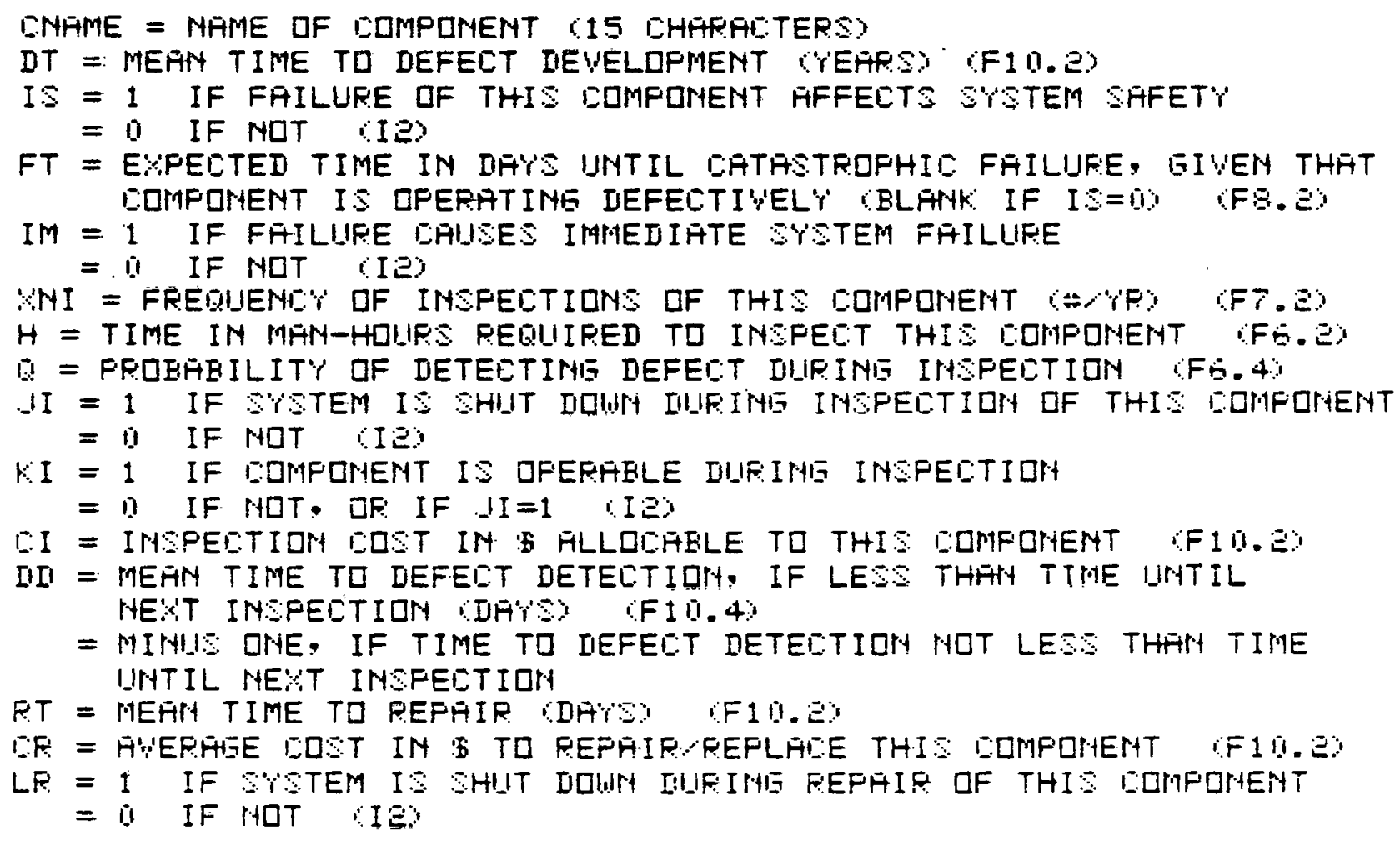


SI FOFMAT 1 IIO

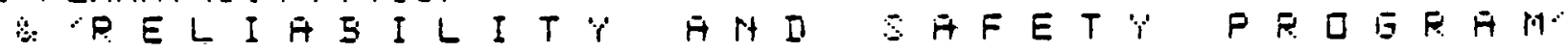

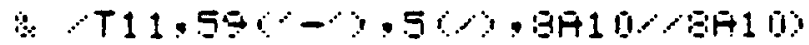

no $70 \quad I=1,14 \cdot 3$

$M=I+\sum$

IF M . BT. HYM=14

FPINT $5.5, K K \cdot K=I \cdot M \%$

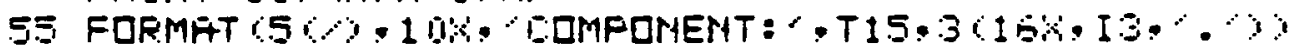

FRINT SO - CLNAME $(J, K), J=1,2), K=I, M$ )

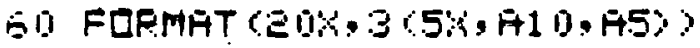

PRINT $5.5,(1, H+D, 1 \mathrm{H}+\mathrm{L}, \mathrm{K}=\mathrm{I}, \mathrm{M}$

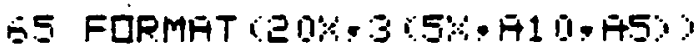

PRIMT $P 1 \cdot(D T$ OK,$K=I \cdot M)$

PPINT $72, C I S O K, K=I, M)$

FPINT 73, GT $(K), K=I, M)$

PRINT $74 . C I M O K, \cdot K=I, M)$

PRINT $75, O H I K O K=I, M)$

PPINT $75 .(H(K) \cdot K=I: 19)$

PPINT $7 F$, $(G)(K), K=I, M)$

PRIAT $73, \triangle J I K O, K=I, M$

PRIKTT 79, OKI KK, $, K=I, M$;

PRINT $310 ., C I K), K=I, 14)$

PRINT $\$ 1$ : CIDCK) $, K=I, M$

FPINT BE: (RT KK) $K=I, M$ )

FPINT $3: 3,(C R, K), K=I, M)$

$7 D$ PRINT $3+$ LLR $(K), K=I, M)$

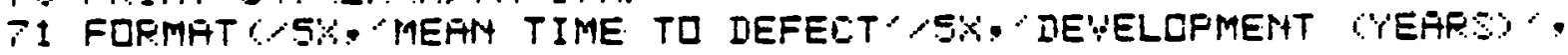
\& T15.3(10\%.F10.Z)

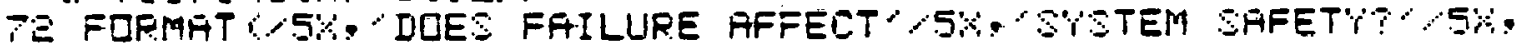

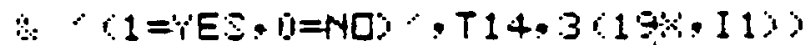

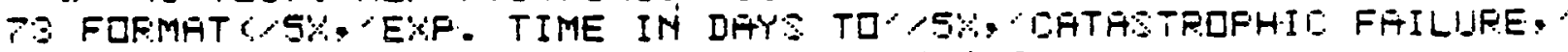

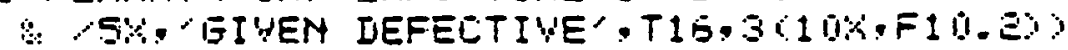

74 FQRMAT $O$ SR, DUES FAILUFE LAUSE SK.

8. 'IMMED. STSTEM FAILURE?' T14-3 C19\% I I

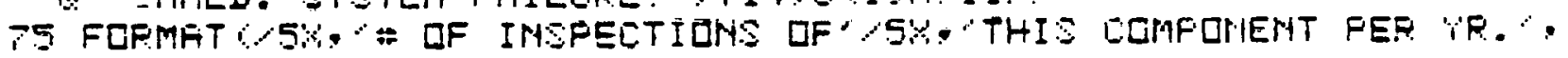

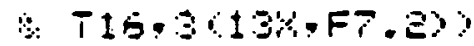

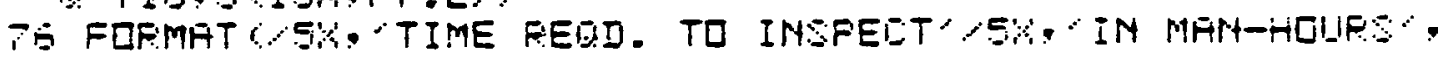

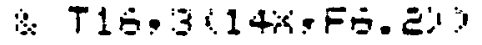

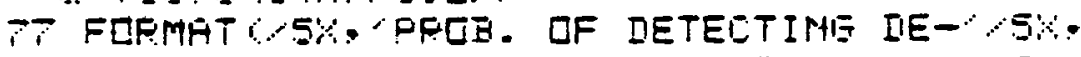

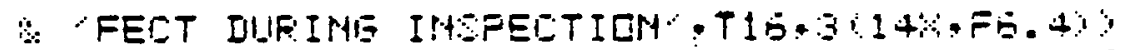

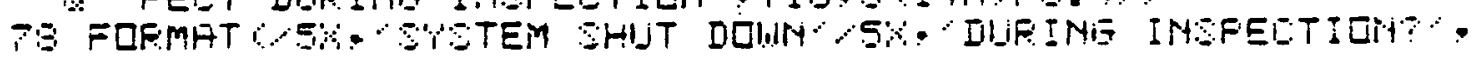

\% $T 14,319 \% \cdot I 13)$

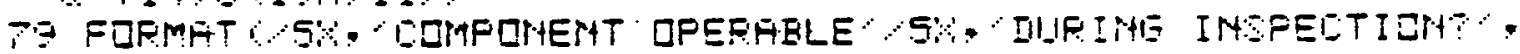

4. $T 14.319 x-I 1.13$

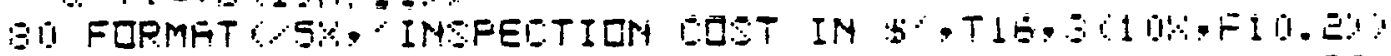

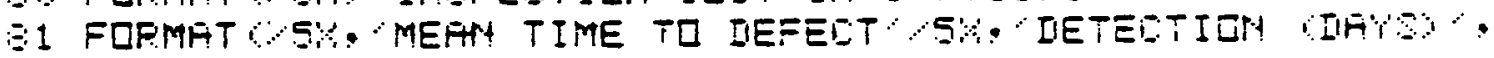

\& T1B.3 O10.,F10.4\%

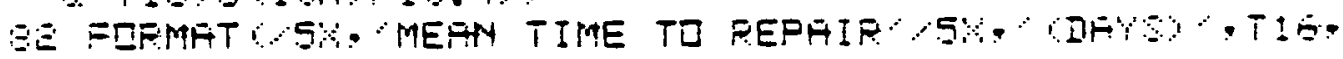

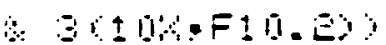

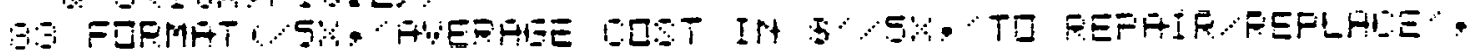

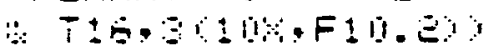

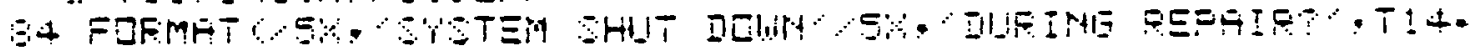

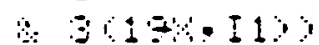


REAI SVSTEM INFUTS

FEAI NLIMEER DF MINIMAL PATH SETS OUF TD 3 ID) AMI MLIMEER DF MINIMFL LUT SETS

PEAII 9II, MF, MC

91) FURMAT (EIS)

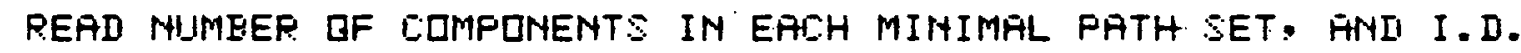
NIIMEEPS DF COMFOMENTS IN IT

IO $110 \mathrm{O} J=1$. MP

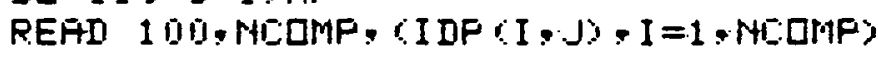

100 FURMAT (อDI 4)

110 NCF $(J)=$ MCOMF

:

E PEFII NIJMEER DF COMFOMEMTS IN EACH MIMIMFL LUT SET,

C ANI I.D. NUIMBERS QF COMPQNENTS IN IT

DO $115 \mathrm{~J}=1 . \mathrm{NL}$

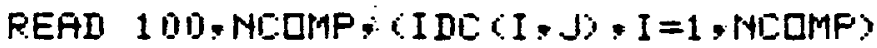

15:

115 NHEC CJ) $=N E$ COMF

E. PRINT FATH SET INFU

FRINT 120

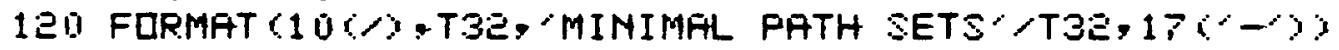

DD $140 \quad J=1: N P$

NCOMP=NCP $(J)$

PPINT 130

130 FOPMAT

DO 1411 I=1, ME:OMP

1411 PPINT 150. CNAME (1. IDPCI .J) . CNAME CE. IDF I. J)

8

150 FQRMAT (T33.A1 I. H.5)

: FPINT EUT SET INFI

PRINT 150

160 FOFMAT $1003, T 33$. MINIMAL CUT SETS TS3.176-O

DO $170, .=1, N D$ :

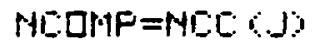

PPINT 130

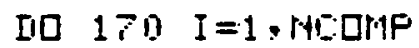

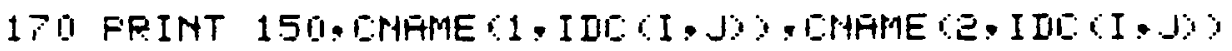

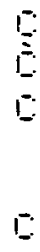

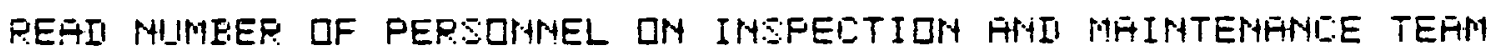
MA'Y BE FPAH:TIDMFLS

FEAI 1 BQ PERS

130 FUFMAT CF. 
D. DOMFITE STATE RESIIENIE DIFATIDHS AHII FFLEFEILITIES

E FUF EALH BOMFUHEHT

[I0 $1: 0 \quad I=1.14$

FINI EATID OF INGPECTIEN TIME TQ HEFMAL

JR LIEFECTI'IE OFEFATIDH TIME

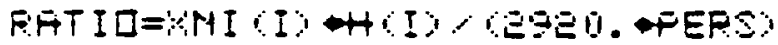

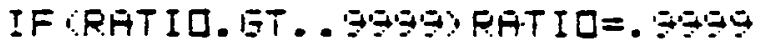

FIHD EXYPECTED TIME TO DETECTIDM DF IEFECT

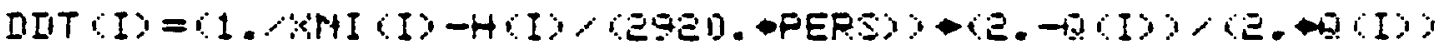

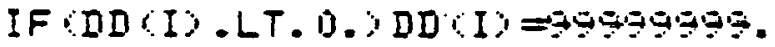

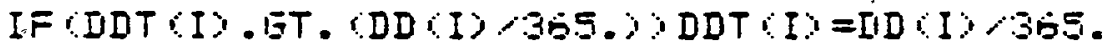

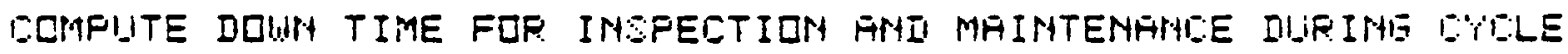

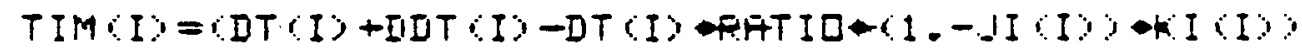

a FATID, (1. -RATID)

FIND UDUM TIME FUF COMPANEMT REPATIP

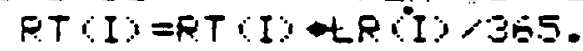

COMFITE IEFECTIUE DPEPATIOM TIME, INGLUIINE FUSSIBLE AFEFIFTIOHA

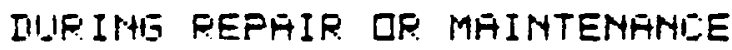
DUT $(I)=I D T(I)+R T(I)-(I-L R(I))+T I M(I)-1-I I(I))$

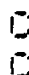

FINI GOMPUHENT GULLE TIME

$Z(I)=D T(I)+D D T(I)+T(I)+T I M(I)$

is

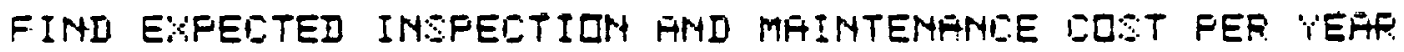

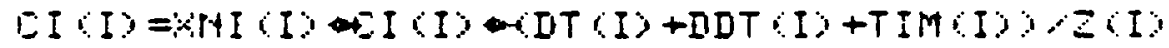

FINI EXFEETED REFAIF, REPLACEMENT GDST FER UERT ER CI $=$ CR (I) ZCI)

FINI PPQBAEILITY QF NDRMAL QFERATIDH FHA $D=D T C O C O$

$1:$

C. FIMI FPQEAEILITY OF DEFECTIUE DFEFATION

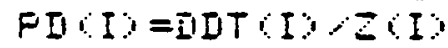

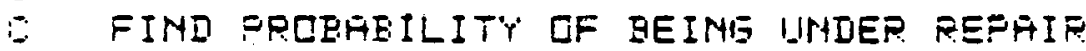

$F C I D=F T I Y Z I)$

$\because$

FINTI PPCEAEILITY OF INSFECTIUN ANHI MAINTENATHE FIMU ID =TIM CIV ECI)

$1:$

DUMPUITE FAILURE RATE, lNHEN DEFEOTIUE

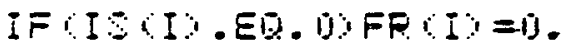

IFCISCI .ED. O,ED TO :BS

IF CFT CIY .EQ. I.OFT IIO=1 . E-

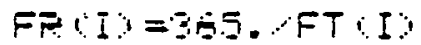

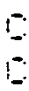

DOMFITE FRCEAEILITH GOMPCHENT IS FFILEI

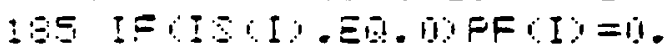

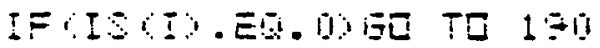

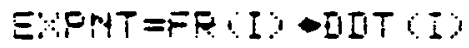

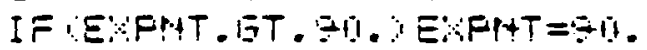

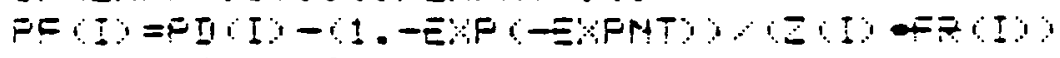


E

E

\section{FRINT EIII}

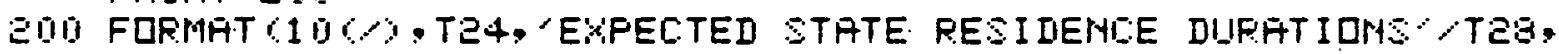

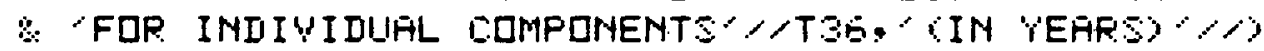

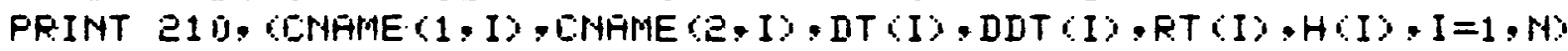

210 FORMAT CT28. 'MOFMAL' * T40, 'DEFECTIVE' TS.5. 'REPAIR' T TS.

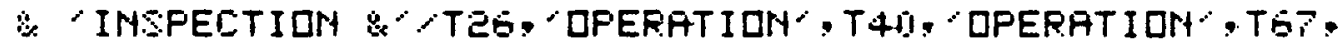

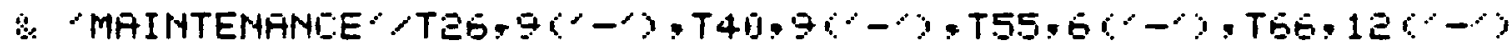

: C.5.A10.75.4F13.5\%;

FRINT EZOD

ZEO FURMAT (5)

\& 'FOP INIIYIDIJAL COMPOHENTS'ハ八

:

:

L

FPINT E10, CLNAME $(1, I)$.CNAME $(2, I), P N C I), P D(I), P P C I), F I M(I), I=1, H)$

\section{FPINT DIT MAINTEMAHAE ANI REPAIR LOSTS}

FRINT 230

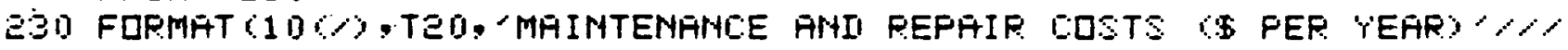

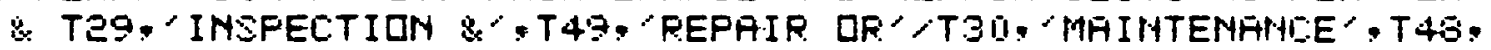

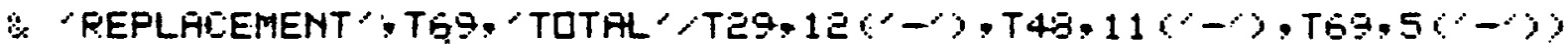

EIM=O.

ERR $=0$.

II $250 \quad I=1 . \mathrm{N}$

ETOT $=I$ I I I) +IER (I)

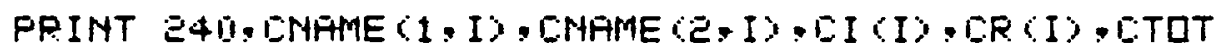

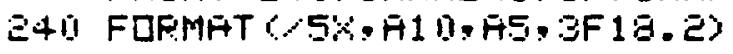

$I I M=I M I M+I I I)$

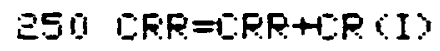

ETRT =EIM+E:RP

FRIMT ESU.EIM.ERR.CTUT

:

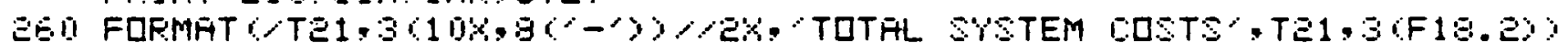

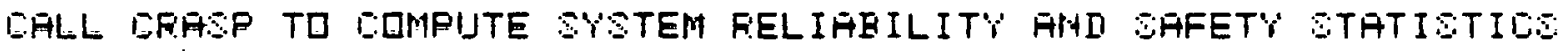

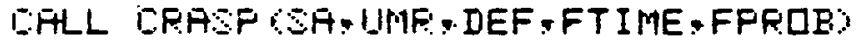

E.

E: FPINT SYSTEM FELIAEILITY AMI SAFET' STATISTIES

FRINT 271 . TITLE. FNITH, SA. IIMF, DEF, FTIME, FFFOE, ETUT

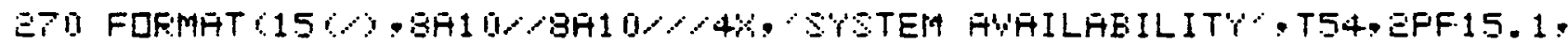

8 $1 \%$ PEPIEENT"

\& T54. EFF1.5.1.1\%. PERCENT $\therefore 4$.

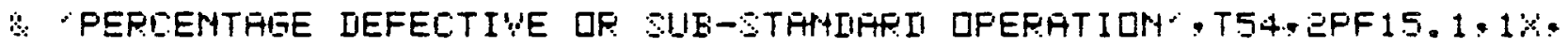

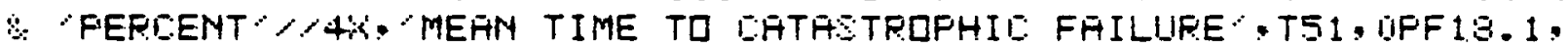

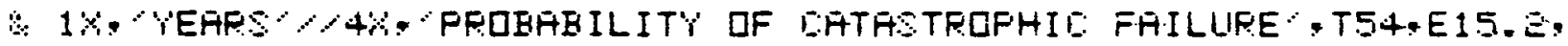

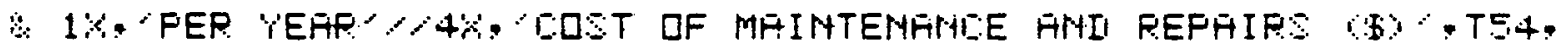

$E$

$\because$ F15. E. $1 \%$ 'FER YEAP'? 
IMWESTIGATE SENSITIUITIES TQ SI FET. IMLFEASE IM MEAPH TIME TU DEFELT IIEUELIFMENT. FUR EFLH DOMPOMENT PRINT ESU

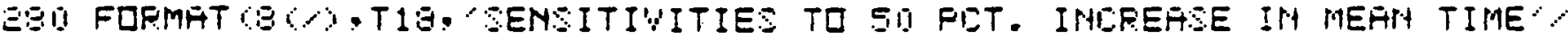

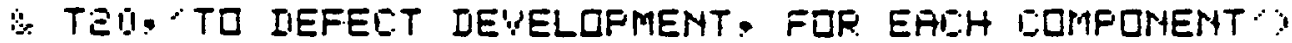
PPINT EQT

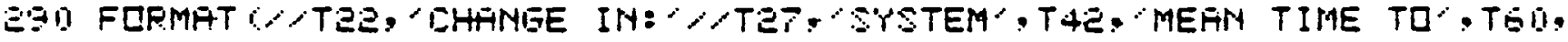

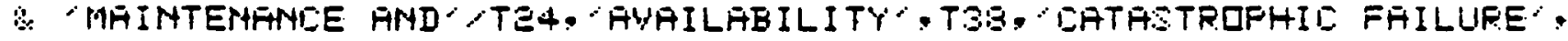

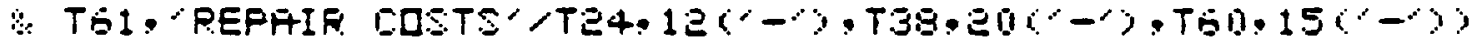

DO $200 \quad I=1 \cdot N$

INEEW $=1.5 \rightarrow D T(D)+D D T(I)+P T(D)+T I M(I)$

FNCI $=1.5 \rightarrow-T$ T $(I), Z$ ZNELW

$P D(I)=D D T(I), Z M E W$

$P P C I)=P T(I)$ ZNEW

PIMIIY =TIMUIY INEW

$F F=F F(I)$

$F F(I)=Z C I)+F F, Z N E W$

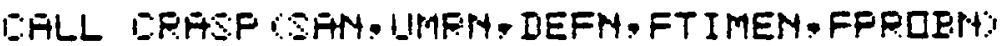

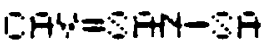

DMTTF=FTIMEN, FTIME-1

FNCI $=0 T(1) / Z(I)$

FD $(I)=I D T(I) / Z(I)$

$P P(I)=R T(I), Z(I)$

PIM $C I)=T I M(I)) Z(I)$

$P F(I)=F F$

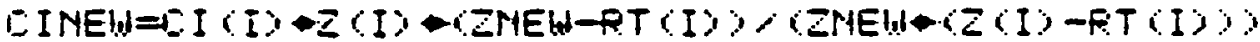

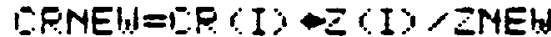

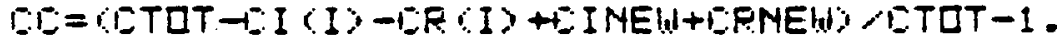

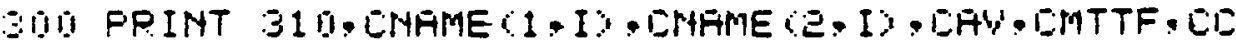

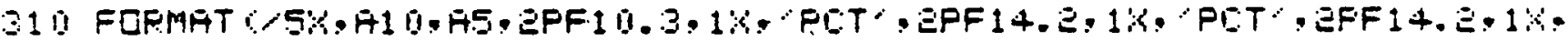
:PLT',

INWESTIGATE SENSITIVITIES TQ 50 PET. IIECREATE IN MEAM TIME

TD DETECT DEFECT

FRIPT :ZE

SEU FUFMAT

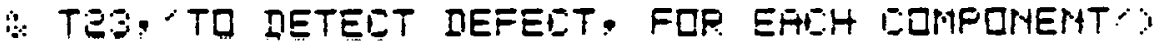

PPINT EY!

Do $3301=1.4$

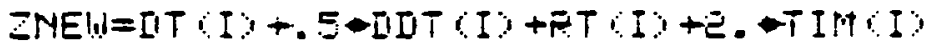

PDCIY=. 5-IDT CIY ZNEWW

FIM TY =E. ATIM IO CONEW

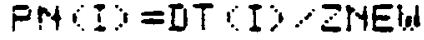

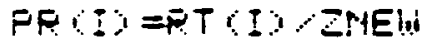

$F F=F F(Y)$

IFCIOCI) .ED. DOFF ID=I.

IF ISCI) . ER. DYGD TU 325

EXPNT $=$. SOFR (ID -DITT CI)

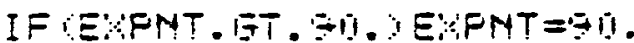

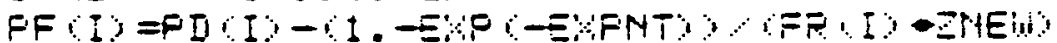

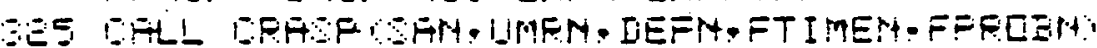




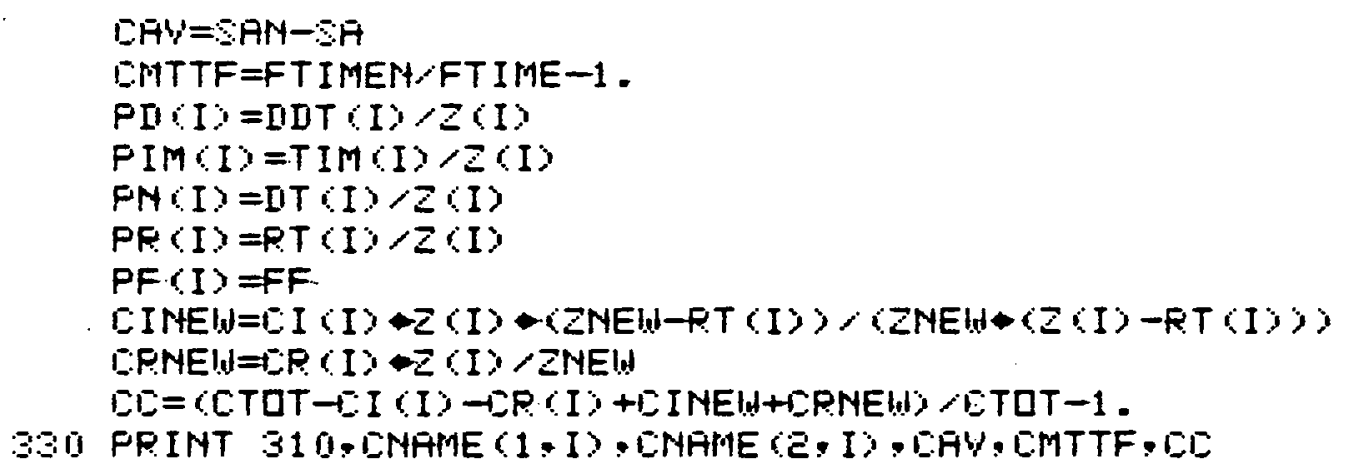

E. INYESTIGATE SENEITIUITIES TO 50 FET. IELREASE IN MEAN TIME TO PEFAIR. PRINT 3410

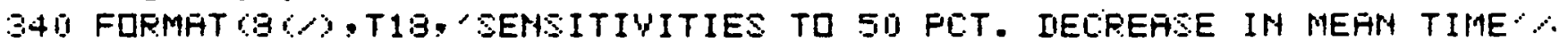

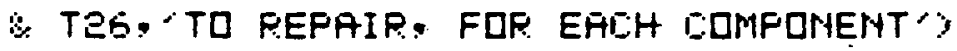

FP.INT 290

ID $350 \quad I=1 . \mathrm{N}$

ZNEW $=D T(I)+N D T(I)+.5+R T(T)+T I M(I)$

PR $(I)=.5-F T(I) / 2 N E W$

$P H C I)=D T(I) / Z N E W$

$P D C I)=D D T(I), Z M E W$

FIM $(I)=T I M(I)$ - ZNEW

$F F=F F(I)$

$P F(I)=Z(I)$ DF $/ Z$ ZNEW

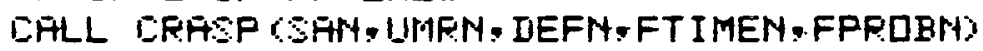

CAMUSANTSA.

CMTTF $=F T$ I MEN $\angle$ FT IME- 1 .

FNCI $=$ ITT $C I D / Z(I)$

PDCI $=D I T(I)-Z C I)$

FR $(I)=R T(I)<Z(I)$

PIMCID $=T I M C I D-2 C I)$

$P F(I)=F F$

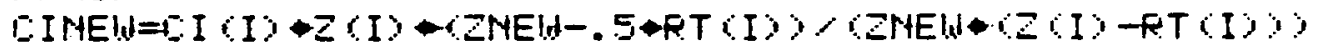

QRMEW $=R$ C $(I)-Z C I)$-ZNEW

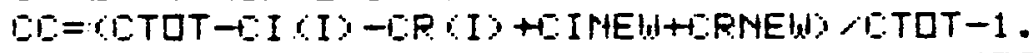

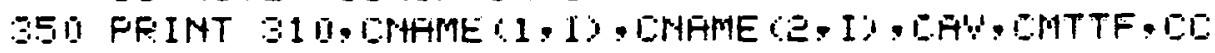

STAF

ErtD

Note: Subroutine CRASP is available upon request. 


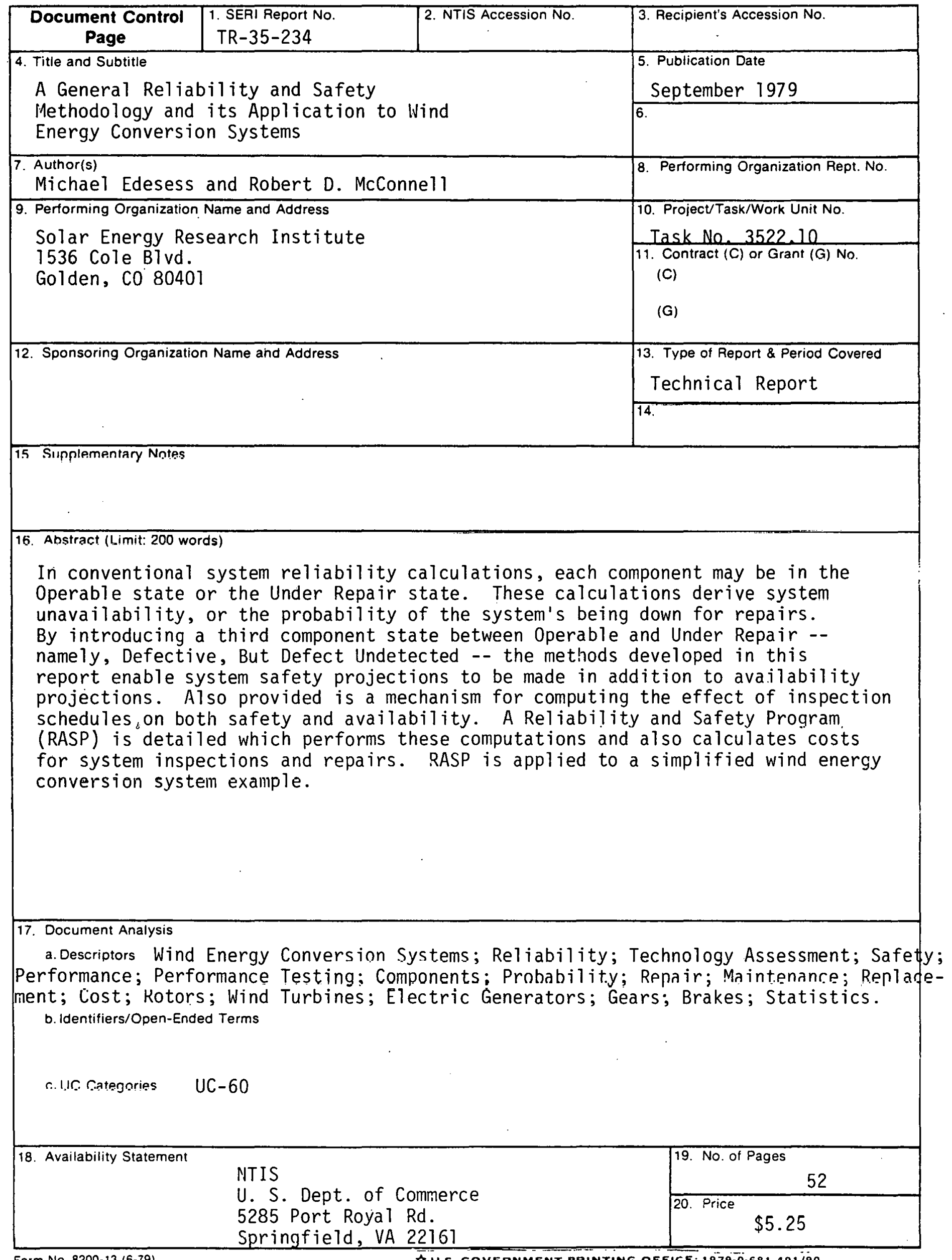

